
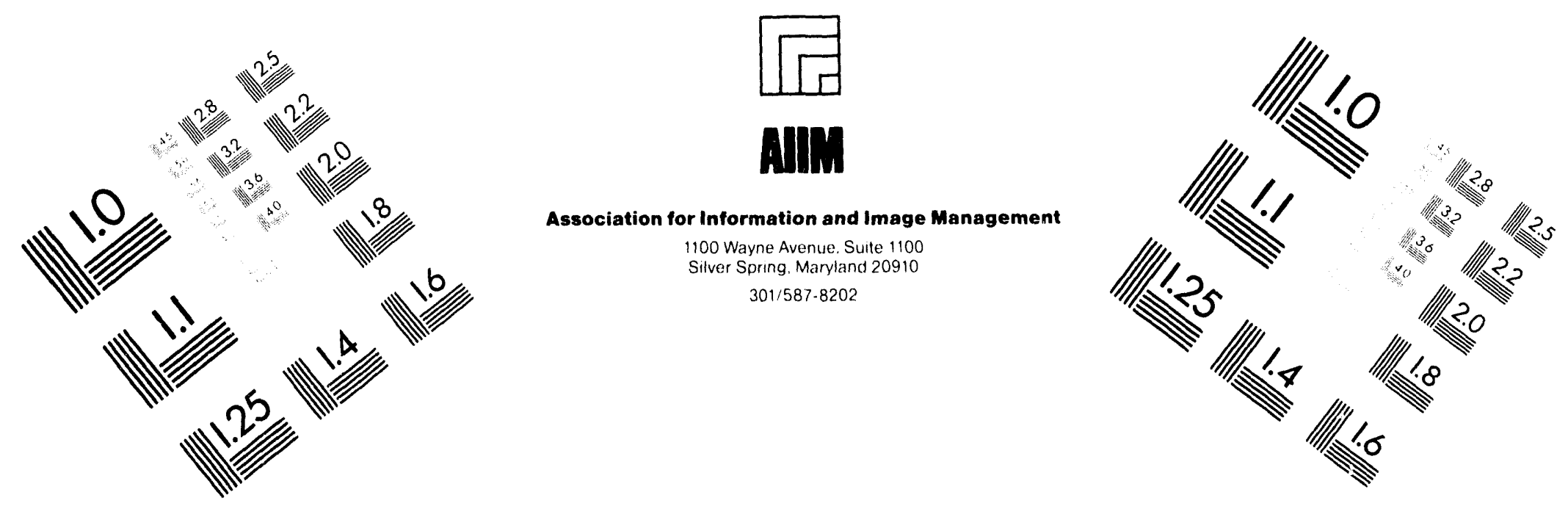

\title{
Centimeter
}

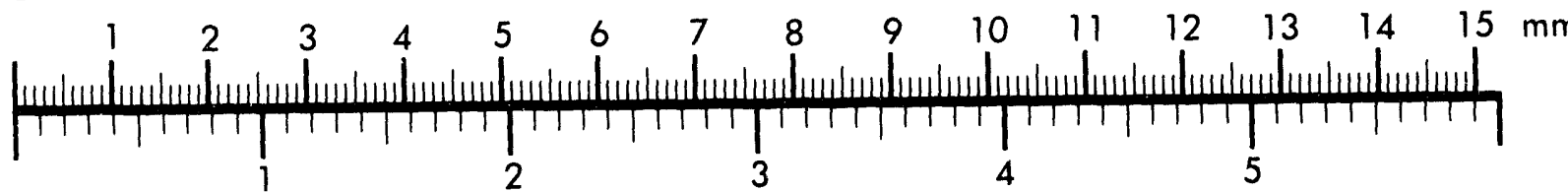

Inches
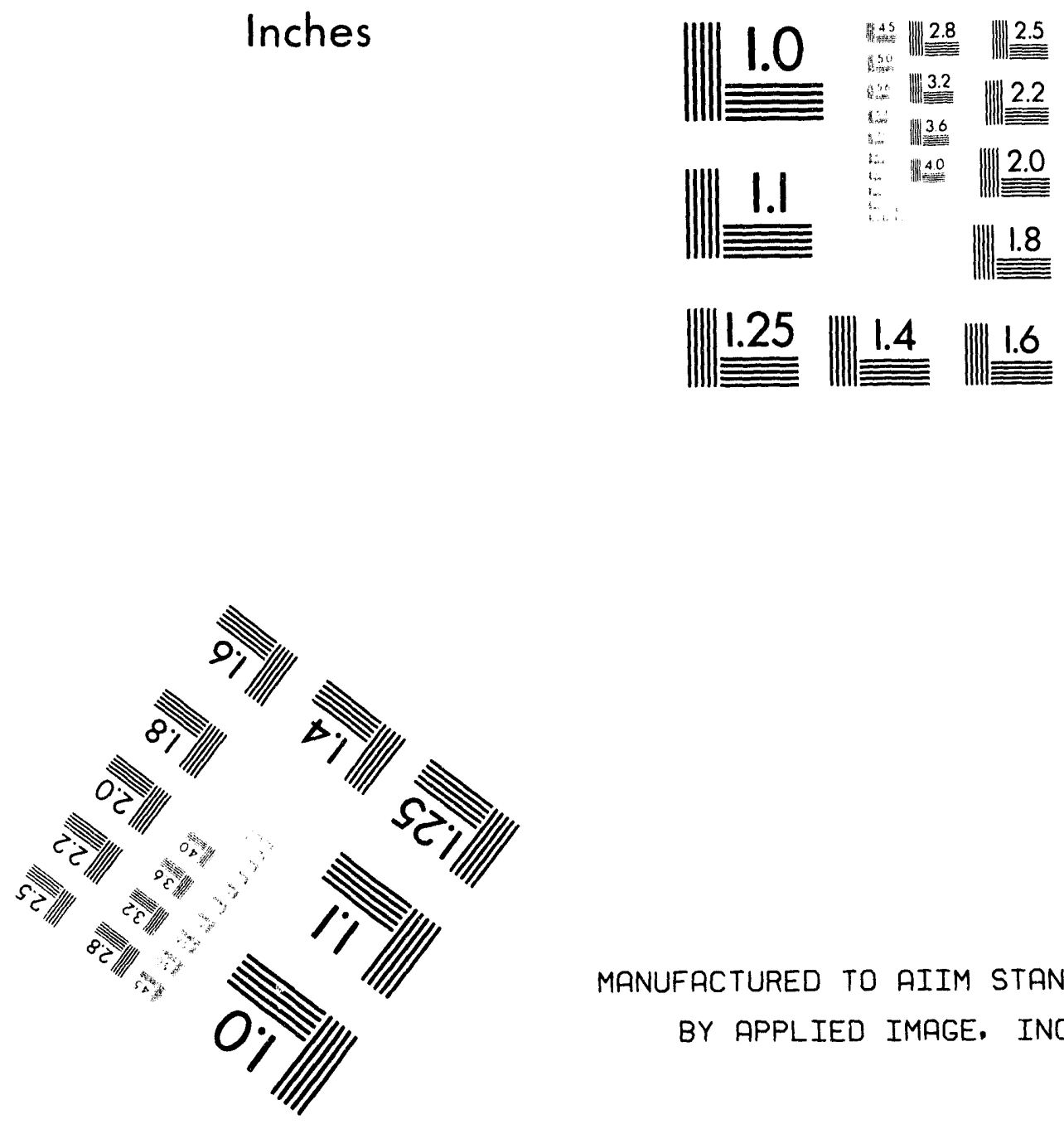

MANUFACTURED TO AIIM STANDARDS

BY APPLIED IMAGE. INC.

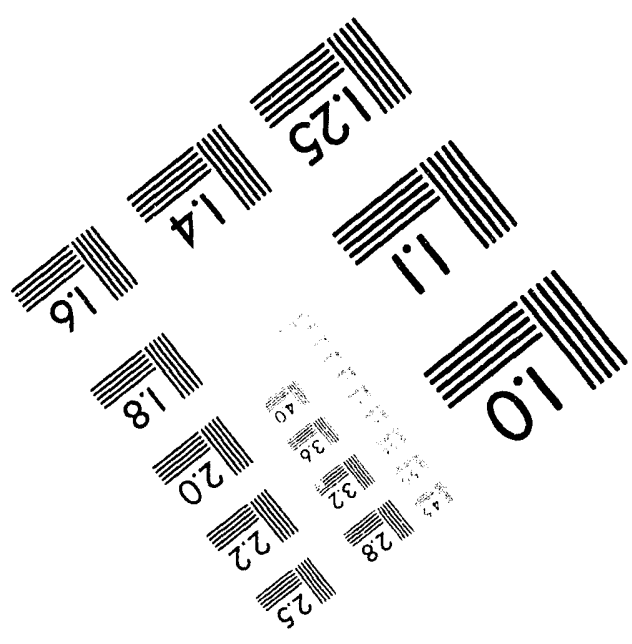



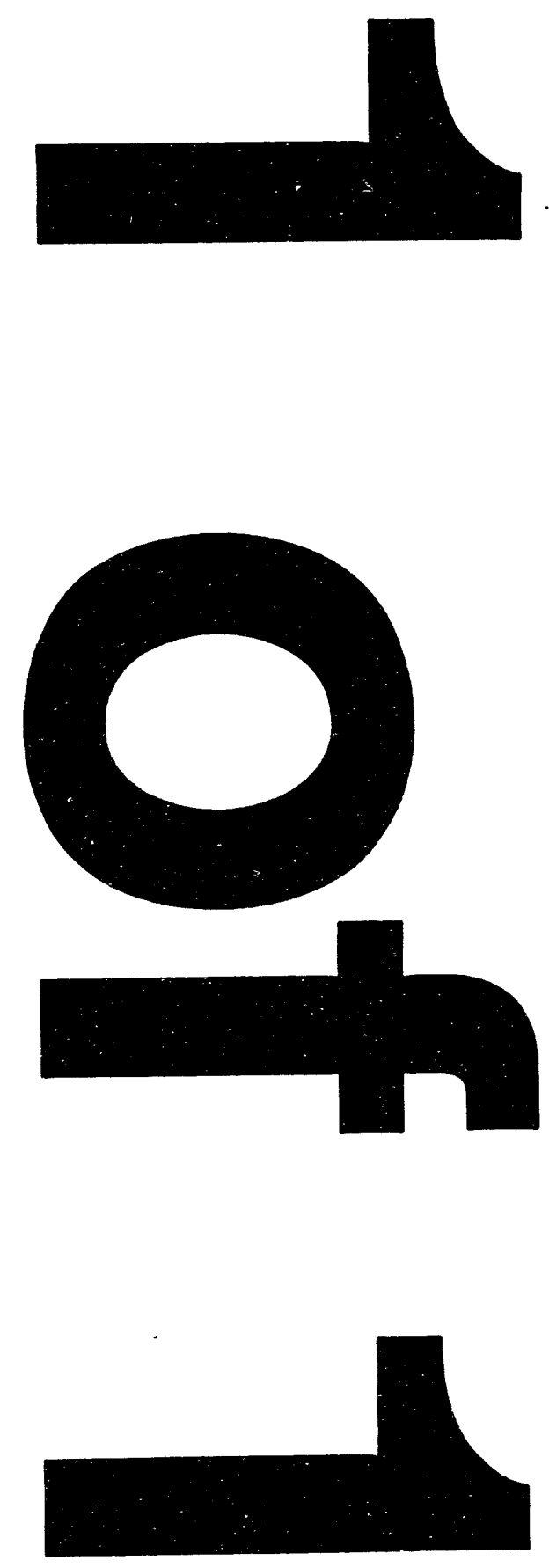
Office of Operational Readiness and

Facility Safety

\section{NUCLEAR ACCIDENT DOSIMETER PROCESSING \\ WITH ATTENUATION FILTERS}

R. J. Gunter

Date Published - May 1994

Prepared by the

OAK RIDGE NATIONAL LABORATORY

Oak Ridge, Tennessee 37831-6494

managed by

MARTIN MARIETTA ENERGY SYSTEMS, INC.

for the

U.S. DEPARTMENT OF ENERGY

under contract DE-AC05-84OR21400 
CONTENTS

Page

UST OF FIGURES $\ldots \ldots \ldots \ldots \ldots \ldots \ldots \ldots \ldots \ldots \ldots \ldots \ldots$

UST OF TABLES $\ldots \ldots \ldots \ldots \ldots \ldots \ldots \ldots \ldots \ldots \ldots \ldots \ldots \ldots \ldots \ldots$ vii

ACKNOWLEDGEMENTS $\ldots \ldots \ldots \ldots \ldots \ldots \ldots \ldots \ldots \ldots \ldots \ldots \ldots \ldots$ ix

ABSTRACT $\ldots \ldots \ldots \ldots \ldots \ldots \ldots \ldots \ldots \ldots \ldots \ldots \ldots \ldots \ldots \ldots \ldots \ldots \ldots \ldots$

1. INTRODUCTION $\ldots \ldots \ldots \ldots \ldots \ldots \ldots \ldots \ldots \ldots \ldots \ldots \ldots \ldots \ldots \ldots$

2. EQUIPMENT AND MATERIALS $\ldots \ldots \ldots \ldots \ldots \ldots \ldots \ldots \ldots \ldots$

2.1 DOSIMETER DESCRIPTION $\ldots \ldots \ldots \ldots \ldots \ldots \ldots \ldots \ldots$

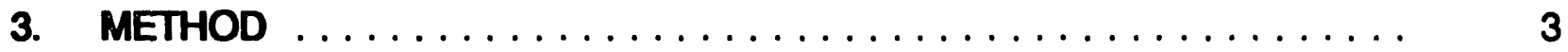

4. EVALUATION OF RESULTS $\ldots \ldots \ldots \ldots \ldots \ldots \ldots \ldots \ldots \ldots$

5. REgULATORY REQUIREMENTS $\ldots \ldots \ldots \ldots \ldots \ldots \ldots \ldots \ldots \ldots$

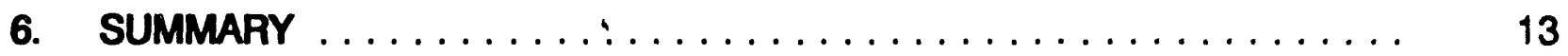

7. FUTURE WORK $\ldots \ldots \ldots \ldots \ldots \ldots \ldots \ldots \ldots \ldots \ldots \ldots \ldots \ldots \ldots$

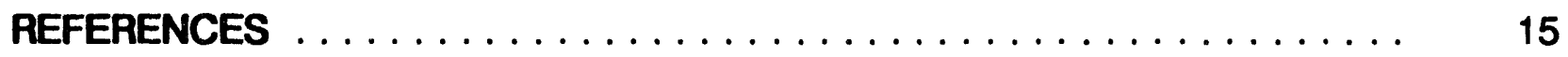




\section{UST OF FIGURES}

Figure

Page

1. CEDS beta-gamma dosimeter assembly configuration $\ldots \ldots \ldots \ldots$

2. Nonsupralinearity-corrected dosimeter response (Reported/Delivered

Dose) using the current dose assessment method for deep dose . . . . .

3. Element 1 average relative response prior to algorithm application .... 


\section{UST OF TABLES}

Table

Page

1. Dosimeter average deep dose performance using routine CEDS dose calculation methods for doses ranging from $10-10,000 \mathrm{rad} . \ldots$.

2. Dosimeter average deep dose performance quotient eliminating supralinearity correction for doses of 100 to $1,000 \mathrm{rad}$

3. Step case determinations based on element ratios $\ldots \ldots \ldots \ldots \ldots$. 9

4. Percent PMT noise contribution to reader calibration card results using the $1 \%$ transmission filter $\ldots \ldots \ldots \ldots \ldots \ldots \ldots \ldots \ldots$

5. Nuclear accident dosimeter performance within dose range requirements of DOE 5480.11

6. Nuclear accident dosimeter performance exposed from 10 - 10,000 rad using Step case 9c for dose calculation 


\section{ACKNOWLEDGEMENTS}

This work was performed at Martin Marietta Energy Systems, Inc., with irradiations performed at the Radiation Standards and Calibration Laboratory (RaSCaL), and TLD processing performed at the Oak Ridge National Laboratory and the Oak Ridge Y-12 Site. The assistance of Ms. K. L. McMahan and Mr. M. L. Souleyrette was instrumental in understanding the factors involved in calibrating the dosimeter readers, and problems that were incurred during this experiment. They also provided a technical review of this paper. The assistance of Mr. R. E. Halliburton, Mr. K. L. Reaves, and Ms. K. G. Sanders at RaSCaL was appreciated for providing TLD irradiation expertise. I would also like to thank Mr. D. S. Colwell and Mr. D. E. Somers for their contributions to this work. 


\title{
NUCLEAR ACCIDENT DOSIMETER PROCESSING WITH ATTENUATION FILTERS
}

\author{
R. J. Gunter
}

\begin{abstract}
An evaluation of the Martin Marietta Energy Systems, Inc., Personnel Nuclear Accident Dosimeters was undertaken to determine if they could meet DOE 5480.11 requirements for photon dose assessment. Dosimeters were irradiated with a ${ }^{137} \mathrm{Cs}$ source to doses ranging from 0.5 to $10,000 \mathrm{rad}$ and processed using transmission fitters to prevent photomultiplier tube saturation. Dose equivalent responses were found to meet the requirements using dosimeter reader number 55. Use of reader number 11 revealed a problem with current procedures. While performing a normal calibration with transmission filters in place it was discovered that there was a high noise component in the calibration signal, resulting in a poor calibration. Dosimeters processed with reader number 11 using a $1 \%$ transmission filter determined element 3 response $30 \%$ below expectations. The low element 3 response resulted in a significantly lower dose calculation for affected dosimeters. Another factor affecting overall response was an excessive supralinearity correction applied to dosimeters exposed between 100 and 1,000 rad.
\end{abstract}

\section{INTRODUCTION}

DOE 5480.11 states that Personnel Nuclear Accident Dosimeters (PNADs) shall be capable of determining gamma dose delivered within a range of 10 to 1,000 rad with an accuracy of $\pm 20 \%$, without dependance on data gained from nearby Fixed Nuclear Accident Dosimeters (FNADs). This experiment assesses the capability of the PNADs and the photon dosimeter portion of the FNADs used by the Centralized External Dosimetry System (CEDS) to report photon dose up to 10,000 rad.

The CEDS uses the routine-issued personnel thermoluminescent dosimeter (TLD) as a PNAD and a component of the FNAD. TLDs exposed to relatively high radiation 
doses emit excessive light resulting in saturation of photomultiplier tubes (PMTs) found in the dosimeter readers. Saturation of PMTs may result in a loss of dosimeter system response and damage to the tubes. Light attenuating optical filters are often used to prevent saturation of PMTs when LiF dosimeters are processed after receiving a relatively high radiation dose.

CEDS Procedure 3-1-500, "Personnel Nuclear Accident Dosimetry," calls for the use of optical filters to prevent PMT saturation while reading dosimeters recording high doses. The procedure calls for using a $10 \%$ transmission filter when processing dosimeters exposed to radiation doses of 50 to $500 \mathrm{rad}$, and a $1 \%$ transmission filter when exposed to greater than $500 \mathrm{rad}$. In the event of an accidental exposure of individuals from a criticality accident or misuse of a large source, the dose to and the population of affected individuals may not be known. If the dose is unknown, an appropriate filter may not be used. This experiment will determine the ability to accurately measure and report doses in the range of 0.5 to 10,000 rad using the Harshaw/Bicron TLD System 8800 Reader and Model 8805 dosimeter card with light attenuating optical filters. Evaluating use of filters over a wide range of dose will indicate whether they can be used in the event of a casualty prior to a full understanding of its severity.

\section{EQUIPMENT AND MATERIALS}

The following equipment and materials will be needed to complete this experiment:

- 90 Harshaw/Bicron $\mathbf{8 8 0 5}$ dosimeter cards in holders on a lucite phantom

- Optical filters for each TLD reader:

- $10 \%$ transmission

- $1 \%$ transmission

- Radiation source:

- Collimated beam ${ }^{137} \mathrm{Cs}$

- TLD processing equipment and services:

- CEDS TLD readers 11 and 55 (Harshaw TLD System 8800 Dosimeter Readers) 


\subsection{DOSIMETER DESCRIPTION}

CEDS uses the Harshaw Model 8805 4-element dosimeter cards with holders providing filtration of incident radiation based on the element position. ${ }^{2}$ Elements 1 and 3 responses are used also as a basis for determining deep and shallow doses, respectively. Elements 1, 2, and 3 are composed of TLD 700 (LiF:Mg,Ti), and element 4 is composed of TLD 600 (LiF:Mg, Ti). TLD 600 contains Lithium with an isotopic composition of $95.6 \%{ }^{\circ} \mathrm{Li}$ and $4.4 \%{ }^{7} \mathrm{Li}$, TLD 700 is composed of approximately $99.99 \%$ ${ }^{7} \mathrm{Li}$. Elements are held in place by a teflon covering. Figure 1 is an illustration of the dosimeter with the associated holder.

\section{METHOD}

In this experiment, 15 groups of 6 PNADs were annealed at $300^{\circ} \mathrm{C}$ and exposed to ${ }^{137} \mathrm{Cs}$ photons $(E=662 \mathrm{keV})$ using the Department of Energy Laboratory Accreditation Program (DOELAP) irradiation protocols. ${ }^{3}$ Once irradiated, dosimeters were evenly divided and processed in accordance with CEDS Procedure 3-1-500, "Personnel Nuclear Accident Dosimetry," using dosimeter readers 11 and 55. Equal numbers of dosimeters exposed to 500 rem or less were processed using both $1 \%$ and $10 \%$ transmission filters. Dosimeters exposed to greater than 500 rem were processed using a $1 \%$ transmission filter. Each TLD was annealed 7 days prior, and processed 24 hours post exposure.

\section{EVALUATION OF RESULTS}

A complete summary of data and graphs is provided on the attached Data and Graph Pages. The data consists of the individual element readings from each dosimeter, the algorithm step case, and reported doses. Reported doses are given prior to and after various correction factors have been applied. The data is divided by the input parameters chosen for the dose assessment algorithm. Input parameters determine which step case would be used to calculate dose for an identified step. Reported doses 


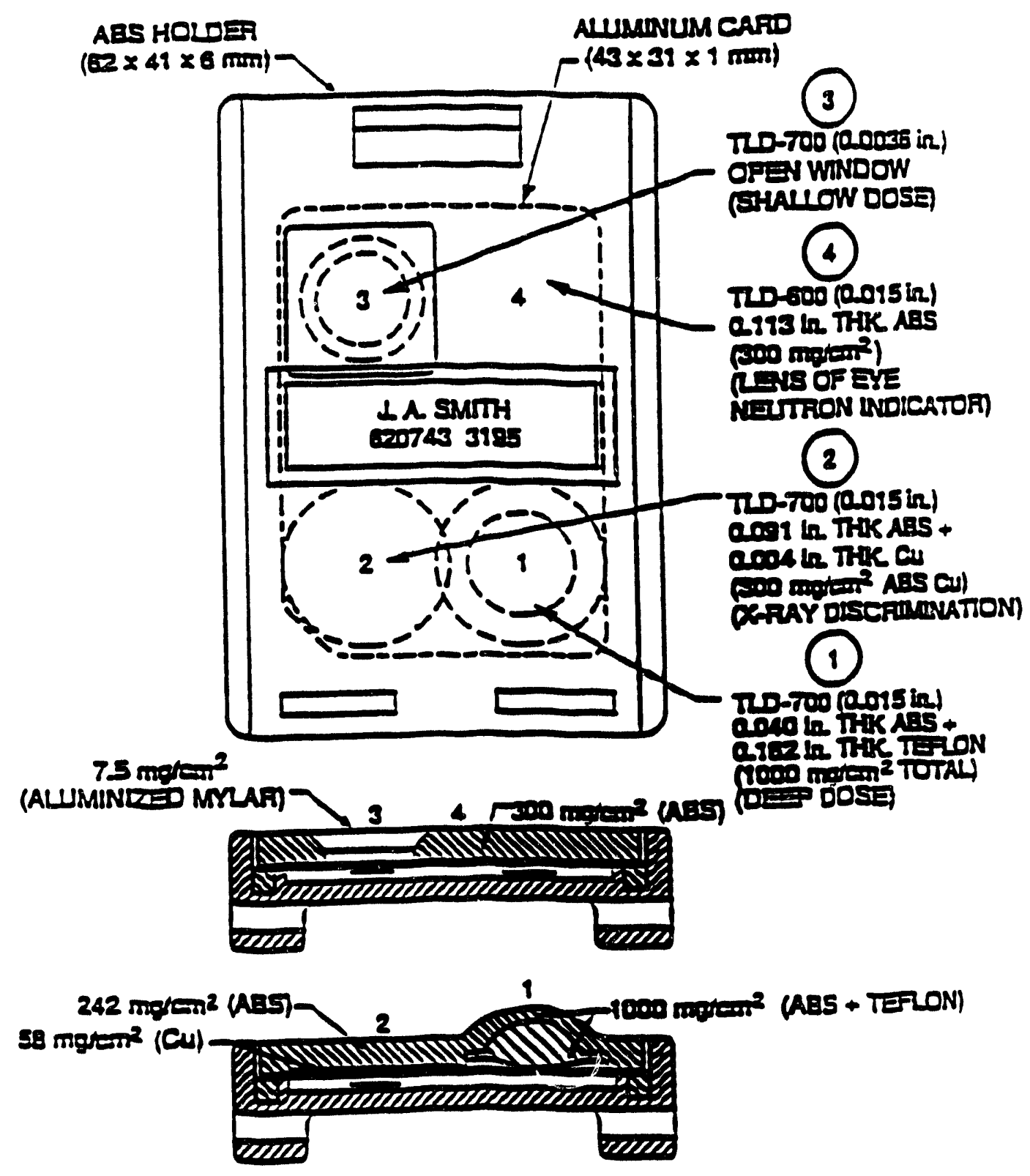

Fig. 1. CEDS beta-gamma dosimeter assembly configuration. Source: Centralized External Dosimetry System, "Technical Basis for the Centralized External Dosimetry System," p. 4-11, Martin Marietta Energy Systems, Inc., Oak Ridge, Tenn., Oct. 4, 1991. 
were calculated with the algorithm methodology used for routine dose assessment. ${ }^{2}$ Dosimeters identified to Step 12 had doses calculated using the method described in the revision of the June 19, 1989 algorithm dated January 26, 1992. The graphs used in this report were produced from attached data. Deep radiation dose refers to that dose deposited behind $1,000 \mathrm{mg} / \mathrm{cm}^{2}$ ABS plastic (element 1 position). Shallow dose is measured beneath $7.50 \mathrm{mg} / \mathrm{cm}^{2}$ mylar foil (element 3 position).

The algorithm methodology employed to calculate radiation dose by CEDS measures the response of four elements in each TLD. Based on their position, elements are shielded with materials chosen for their ability to attenuate ionizing radiation. Ratios of element responses are used to determine the source of ionizing radiation to which the dosimeter was exposed. The ratios determine the algorithm step used to calculate dose. Since many sources of radiation may exhibit similar characteristics, the user may choose to assume specific sources for some conditions and assign a step case. The step case is chosen based on the most likely sources encountered by an individual at the site. In the event of a ${ }^{137} \mathrm{Cs}$ exposure, as in this experiment, the algorithm is designed to determine the field as high energy photons and use Step 9 to calculate dose. The algorithm steps ${ }^{2}$ and step cases identified while processing dosimeters for this experiment dose are as follows:

Step 9: High Energy Photons. Two cases were assumed for this experiment. Step case $9 \mathrm{a}$ assumes the high energy photon source is pure ${ }^{137} \mathrm{Cs}$. Step case $9 \mathrm{c}$ assumes a mixture of sources including ${ }^{137} \mathrm{Cs}, \mathrm{H} 150$, and M150 X-rays.

Step 10: Beta Component Mixed with High Energy Photons. Step case 10b assumes the beta component is either ${ }^{00} \mathrm{Sr} / \mathrm{N}$ or ${ }^{204} \mathrm{TI}$, and the high energy photons are contributed by a mixture of sources including ${ }^{137} \mathrm{Cs}, \mathrm{H} 150$, and M150 X-rays.

Step 11: Beta Component Mixed with Low Energy Photons. Step case $11 \mathrm{~b}$ assumes the beta component is either ${ }^{90} \mathrm{Sr} / \mathrm{N}$ or ${ }^{204} \mathrm{Tl}$, mixed with low energy photons. 
Step 12: Photons of Various Energies. Step 12 is the algorithm default step. It assumes there are photons of various energies in the field exposed. If no other step is identified based on the ratios of element response, the algorithm will default to Step 12 for dose calculation.

Table 1 gives a statistical performance assessment of dosimeter results. The combined performance of results from readers 11 and 55 meets the requirements of DOE Order 5480.11 in 2 of 4 cases. Combined results using the $1 \%$ transmission filter and choosing Step cases $9 c, 10 c$, and $11 c$ do not meet the performance requirements for PNADs or FNADs. The results from reader 11 using a $1 \%$ transmission filter fail to meet the performance requirements regardless of the step cases chosen. Table 1 presents average dosimeter performance for deep dose determined using the routine CEDS methodology. Performance is measured as the average bias associated with all dosimeters in the group of interest. The bias $(B)$ is the difference between the reported and delivered dose divided by the delivered dose. Performance of both readers using a $10 \%$ transmission filter yielded acceptable results. Graphs of average dosimeter bias from individual readers can be found on the Graph Pages.

Table 1. Dosimeter average deep dose performance using routine CEDS dose calculation methods for doses ranging from $10-10,000$ rad

\begin{tabular}{|c|c|c|c|}
\hline $\begin{array}{c}\text { Filter and Algorithm } \\
\text { Step Case }\end{array}$ & $\begin{array}{c}\text { Dosimeter Reader 11 } \\
\text { Performance }\end{array}$ & $\begin{array}{c}\text { Dosimeter Reader 55 } \\
\text { Performance }\end{array}$ & $\begin{array}{c}\text { Combined } \\
\text { Performance }\end{array}$ \\
\hline $\begin{array}{c}\text { 10\% Trans. Filter } \\
\text { Step 9a, 10b, 11b }\end{array}$ & -0.018 & -0.041 & -0.030 \\
\hline $\begin{array}{c}1 \% \text { Trans. Filter } \\
\text { Step 9a, 10b, 11b }\end{array}$ & -0.241 & -0.066 & -0.153 \\
\hline $\begin{array}{c}10 \% \text { Trans. Fitter } \\
\text { Step 9c, 10c, 11c }\end{array}$ & -0.088 & -0.133 & -0.110 \\
\hline $\begin{array}{c}1 \% \text { Trans. Fitter } \\
\text { Step 9c, 10c, 11c }\end{array}$ & -0.267 & -0.142 & -0.205 \\
\hline
\end{tabular}


A review of the graphs comparing supralinearity and nonsupralinearity-corrected dosimeter response demonstrates decreased performance for supralinearity-corrected (SL) dose in the range of 100 to 1,000 rad. The doses reported without supralinearity correction yield a lower absolute bias for dosimeters irradiated from 100 to 1,000 rad. If the supralinearity correction is removed for these dosimeters, overall performance would improve. Removing the supralinearity correction at doses in this range allowed the CEDS PNADs and FNADs to pass the acceptance criteria in most cases. Note, however, in Table 2 the continued poor performance of reader 11 with the $1 \%$ filter.

Table 2. Dosimeter average deep dose performance quotient eliminating supralinearity correction for doses of 100 to 1,000 rad

\begin{tabular}{|c|c|c|c|}
\hline $\begin{array}{c}\text { Fitter and Algorthm } \\
\text { Step Case }\end{array}$ & $\begin{array}{c}\text { Dosimeter Reader 11 } \\
\text { Performance }\end{array}$ & $\begin{array}{c}\text { Dosimeter Reader 55 } \\
\text { Performance }\end{array}$ & $\begin{array}{c}\text { Combined } \\
\text { Performance }\end{array}$ \\
\hline $\begin{array}{c}\text { 10\% Trans. Fitter } \\
\text { Step 9a, 10b, 11b }\end{array}$ & 0.043 & 0.012 & 0.028 \\
\hline $\begin{array}{c}\text { 1\% Trans. Filter } \\
\text { Step 9a, 10b, 11b }\end{array}$ & -0.189 & -0.003 & -0.096 \\
\hline $\begin{array}{c}10 \% \text { Trans. Filter } \\
\text { Step 9c, 10c, 11c }\end{array}$ & -0.051 & -0.066 & -0.058 \\
\hline $\begin{array}{c}1 \% \text { Trans. Filter } \\
\text { Step 9c, 10c, 11c }\end{array}$ & -0.218 & -0.083 & -0.151 \\
\hline
\end{tabular}

Figure 2 illustrates the relative response of dosimeters processed with reader 55 using nonsupralinearity-corrected reported dose. Figure 3 illustrates nonsupralinearitycorrected relative element 1 response of these same dosimeters. Figure 3 agrees with previously-recorded findings demonstrating a supralinearity effect starting at approximately $100 \mathrm{rad}$, with an increase beyond $1,000 \mathrm{rad}^{4.5}$

The reported doses calculated in this study were performed using a methodology based on response of the multiple elements located in the TLD. As seen in the Data Pages and in Table 3, more than one algorithm step was identified while reading the 


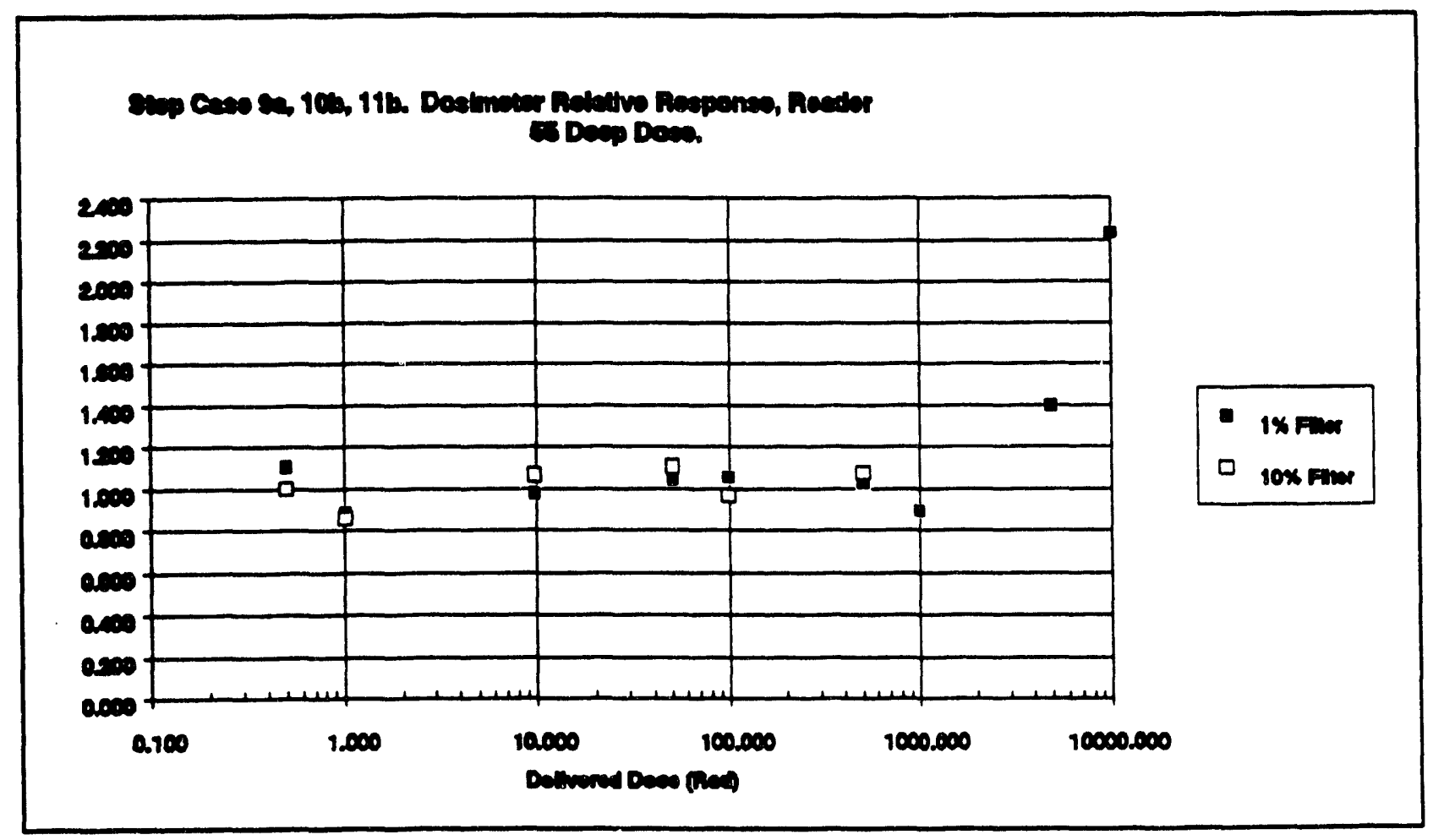

Fig. 2. Nonsupralinearity-corrected dosimeter response (Reported/Delivered Dose) using the current dose assessment method for deep dose.

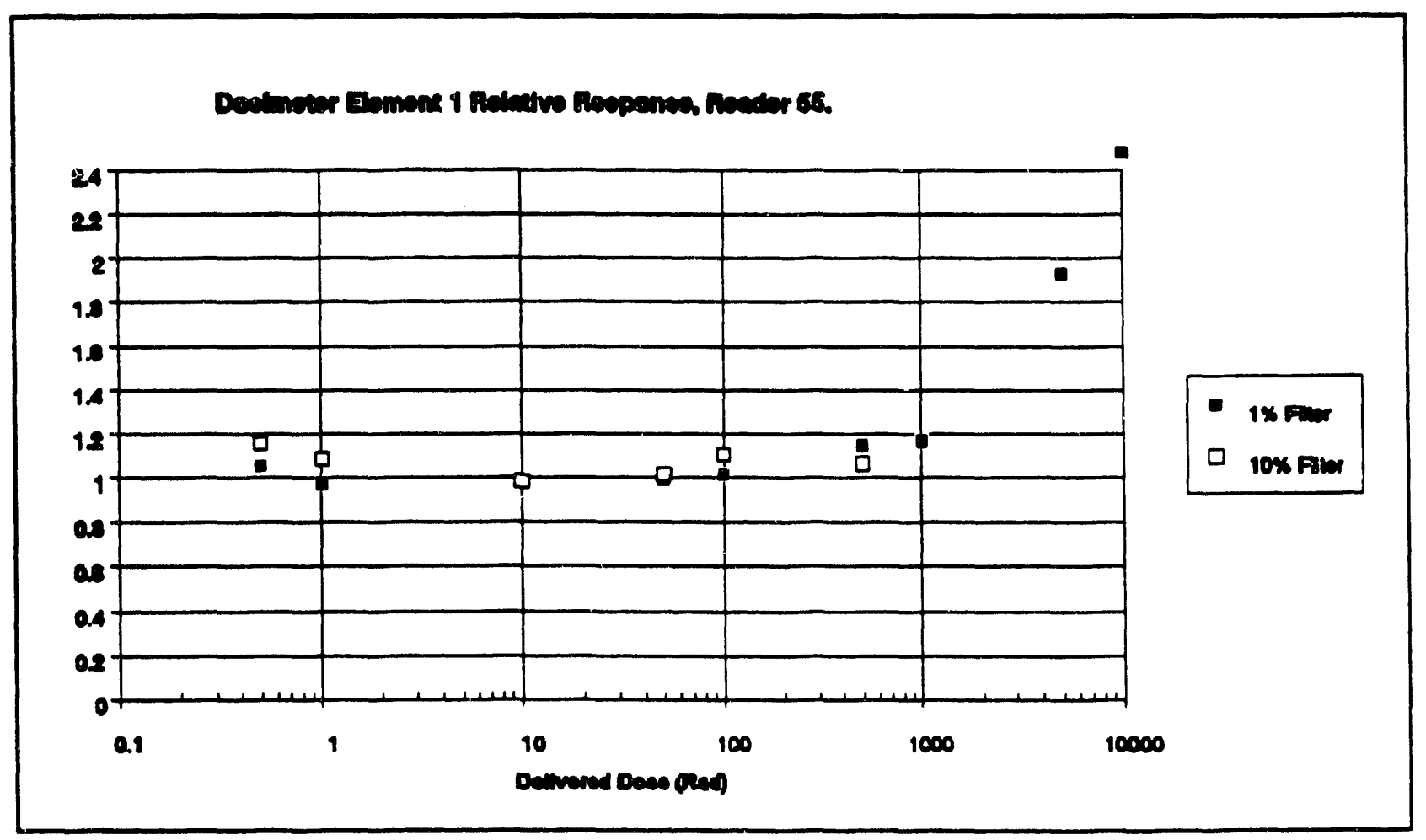

Fig. 3. Element 1 average relative response prior to algorithm application. 
9

Table 3. Step case determinations based on element ratios ${ }^{2}$

\begin{tabular}{|c|c|c|c|c|}
\hline $\begin{array}{c}\text { Transmission } \\
\text { Fiter - Reader } \\
\text { Number }\end{array}$ & Step Case 9 & Step Case 10 & Step Case 11 & Step Case 12 \\
\hline $1 \%-11$ & 8 & 1 & 0 & 18 \\
\hline $1 \%-55$ & 21 & 0 & 0 & 6 \\
\hline $10 \%-11$ & 16 & 0 & 0 & 2 \\
\hline $10 \%-55$ & 13 & 1 & 1 & 3 \\
\hline $1 \%-$ Both & 29 & 1 & 0 & 24 \\
\hline $10 \%-$ Both & 29 & 1 & 1 & 5 \\
\hline
\end{tabular}

dosimeters. Calculation of dose using steps other than Step 9 results in a higher statistical spread than the uncorrected element 1 response. This is due to differences in the method of dose calculation.

A frequency of step case identification is found in Table 3. A significant number of step case misidentifications (other than Step 9) occurred with reader 11 while using the $1 \%$ transmission filter. The rate is much higher than that found with reader 11 using the $10 \%$ fiter, or data obtained with reader 55 using either the $1 \%$ or $10 \%$ filter. The step identified determines what factors will be used to calculate dose. If more than one step is identified, a higher standard deviation in the reported dose than found with individual element readings will result. Most misidentifications resulted in calculating dose using algorithm Step 12. Calculating dose with Step 12 resulted in reported average bias 0.249 lower than using Step case $9 c$ (Step $9 c$ already has a 10\% negative bias), mostly due to the use of element 3 response in calculation of deep and shallow dose for Step 12.

A factor in the high rate of Step 12 identification and the subsequent poor results obtained from reader 11 with a 1\% filter, is an unusually low element 3 (L3) response. This resulted in ratios of $L 3 / L 2$ and $L 3 / L 1$ less than 0.7 , a ratio not anticipated for $a{ }^{137} C s$ exposure. The proper $L 3 / L 2$ and $L 3 / L 1$ ratios for Step 9 identification would have been in the range $0.7<L 3 / L 2: L 3 / L 1<1.1$. Ideally the value would be 1.0 . Ratios less than the 
0.7 value implies measured deep dose (measured at $1,000 \mathrm{mg} / \mathrm{cm}^{2}$ density thickness) was over $30 \%$ higher than shallow dose $\left(7 \mathrm{mg} / \mathrm{cm}^{2}\right)$ I Ratios of $L 3 / \mathrm{L} 1$ and L3/L2 below 0.7 have not been previously found with any dosimeters irradiated with ${ }^{137} \mathrm{Cs}$. Nearly all of the misidentified dosimeters processed with reader 11 using the $1 \%$ filter had their dose calculated using Step 12 as a result of a low L3/L1 and/or L3/L2 ratio. Calculating dose using Step 9 would significantly improve deep dose performance, as element 3 results would not be used. Shallow dose would still be adversely affected.

A ratio of $L 3 / L 2$ or $L 3 / L 1$ less than 0.7 is an unusual occurrence for exposure to photons of this energy. Further study of the dosimeter calibration process has uncovered a likely cause. Prior to reading dosimeters, a calibration was performed with the transmission filters in place. Using transmission filters reduces the calibration signal to $1 \%$ of its usual value. Reducing the calibration signal to $1 \%$ of its original value raises the relative contribution of PMT noise to the total signal.

The typical response of element 3 on a calibration card irradiated to $500 \mathrm{mr}^{*}$ is about $50-60 \mathrm{nc}$. The photomultiplier tube noise during a routine calibration is relatively insignificant, with a maximum specification of about $0.5 \mathrm{nc}$. If the calibration is performed with a $1 \%$ transmission filter in place, the significance of PMT noise is greatly increased. During this experiment, the noise level of the element 3 PMT in reader 11 was approximately $0.25 \mathrm{nc}$, and element 3 PMT of reader 55 was $0.05 \mathrm{nc}$. Use of a $1 \%$ transmission filter reduced the calibration signal to only $1 \%$ of the usual value. At this level, about $33 \%$ of the total signal used for element 3 calibration in reader 11 will be noise. Table 4 lists the average percentage of PMT noise in the calibration signal for all calibration cards read with a 1\% filter in both readers. Reader 55 element 3 had a PMT noise contribution of only $8.1 \%$. For this reason, reader 55 results were not as significantly affected.

The high noise component resulted in a higher than actual nc/mrad calibration factor, yielding a lower reported response for the affected elements. A noise contribution of $30 \%$ for element 3 would account for the unusually low $L 3 / L 1$ and $L 3 / L 2$ ratios seen with reader 11 using a $1 \%$ filter. Elements 1,2 , and 4 did not display this effect because the dose response of these elements from the calibration cards was a much larger percentage of the calibration signal. Elements 1, 2, and 4 have a larger mass than 
Table 4. Percent PMT noise contribution to reader calibration card results using the $1 \%$ transmission filter

\begin{tabular}{|l|c|c|c|c|}
\hline & Element 1 & Element 2 & Element 3 & Element 4 \\
\hline Reader 11 & $4.7 \%$ & $3.6 \%$ & $30.7 \%$ & $3.4 \%$ \\
\hline Reader 55 & $4.2 \%$ & $3.3 \%$ & $8.1 \%$ & $1.5 \%$ \\
\hline
\end{tabular}

element 3, with dose response a factor of 3 to 6 higher. The higher dose response combined with a lower PMT noise for these element positions resulted in a lower percentage of the total calibration signal contributed by noise. Reader 55 element 3 noise only contributed $8 \%$ of the total signal. For this reason, the $L 3 / L 2$ and $L 3 / L 1$ ratios seen with reader 55 did not cause the algorithm to calculate dose with Step 12 (L3/L2 or L3/L1 less than 0.7).

\section{REGULATORY REQUIREMENTS}

The Radiological Controls Manual (DOE/EH-0256T) states that DOE 5480.11 specifies the requirements for a Nuclear Accident Dosimetry Program. These requirements can be found in Paragraphs 5480.11.9.q.(1-3). In summary, the requirements for gamma dosimetry are as follows:

1. The gamma ray components of FNADs shall be capable of measuring fission gamma radiation in the presence of neutrons with an accuracy of approximately $\pm 20 \%$. The gamma dose recording range of these dosimeters shall be 10 to 10,000 rem.

2. The gamma ray components of PNADs shall be capable of determining gamma dose from 10 to 10,000 rad with an accuracy of $\pm 20 \%$.

This experiment exposed the dosimeters to ${ }^{137} \mathrm{Cs}$ without exposure to neutrons to test the light attenuating filters. Table 5 presents the results for the dose range required in DOE 5480.11. 
Table 5. Nuclear accident dosimeter performance within dose range requirements of DOE 5480.11

\begin{tabular}{||c|c|c|c||}
\hline $\begin{array}{c}\text { Step Case and Filters } \\
\text { Used }\end{array}$ & $\begin{array}{c}\text { Reader 11 } \\
(10-1 \mathrm{krad} / \\
10-10 \mathrm{krad})\end{array}$ & $\begin{array}{c}\text { Reader } 55 \\
(10-1 \mathrm{krad} / \\
10-10 \mathrm{krad})\end{array}$ & $\begin{array}{c}\text { Combined Results } \\
(10-1 \mathrm{krad} / \\
10-10 \mathrm{krad})\end{array}$ \\
\hline $\begin{array}{c}\text { Step Case 9a, 10b, } \\
11 \mathrm{~b} ; 1 \% \text { Filter }\end{array}$ & $-0.328 /-0.289$ & $-0.118 /-0.082$ & $-0.223 /-0.186$ \\
\hline $\begin{array}{c}\text { Step Case 9c, 10c, } \\
11 \mathrm{c} ; 1 \% \text { Fiter }\end{array}$ & $-0.343 /-0.304$ & $-0.183 /-0.148$ & $-0.263 /-0.226$ \\
\hline $\begin{array}{c}\text { Step Case 9a, 10b, } \\
11 \mathrm{~b} ; 1 \& 10 \% \text { Filter }\end{array}$ & $-0.079 /-0.111$ & $-0.093 /-0.064$ & $-0.086 /-0.087$ \\
\hline $\begin{array}{c}\text { Step Case 9c, 10c, } \\
11 \mathrm{c} ; 1 \& 10 \% \text { Filter }\end{array}$ & $-0.151 /-0.166$ & $-0.162 /-0.133$ & $-0.156 /-0.150$ \\
\hline
\end{tabular}

*The $10 \%$ transmission filter was used for dosimeters exposed to 500 rad or less.

Results from reader 55 indicate that the PNADs are capable of meeting the

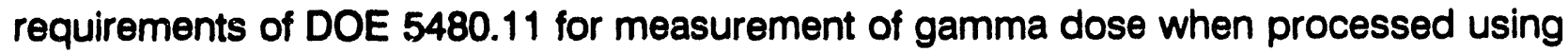
a $1 \%$ transmission filter. The results from reader 11 are poor, but this is due to faulty element 3 readings. Table 6 demonstrates the effectiveness of using a $1 \%$ filter for doses within the dose range of interest when the PMT noise is not a significant factor. Results are calculated by forcing the algorithm to use Step case $9 c$ (only element 1 response used for dose calculation). Table 6 also lists results obtained using current supralinearity corrections, and those with supralinearity correction applied only to dosimeters exposed greater than or equal to 5,000 rad. These results indicate an excessive supralinearity correction for doses less than or equal to 1,000 rad.

A review of the attached data and graphs illustrates that the dosimetry system is capable of accurately reading dose as low as 0.5 rem with a $1 \%$ transmission filter installed. The ability to accurately record dose at a level of 0.5 rem indicates that low doses can be measured with a $1 \%$ filter in place. This would allow for use of a $1 \%$ filter when reading dosimeters immediately after an accident, and before the extent of dose is fully understood, without losing important dosimetry results. 
Table 6. Nuclear accident dosimeter performance exposed from $10-10,000 \mathrm{rad}$ using Step case $9 \mathrm{c}$ for dose calculation

\begin{tabular}{|c|c|c|c|}
\hline & $\begin{array}{c}\text { Reader 11 } \\
\text { Performance Quotient } \\
\text { / Standard Deviation }\end{array}$ & $\begin{array}{c}\text { Reader 55 } \\
\text { Performance Quotient } \\
\text { / Standard Deviation }\end{array}$ & $\begin{array}{c}\text { Combined } \\
\text { Performance Quotient } \\
\text { / Standard Deviation }\end{array}$ \\
\hline $\begin{array}{c}\text { Current supralinearity } \\
\text { correction method }\end{array}$ & $-0.114 / 0.137$ & $-0.087 / 0.125$ & $-0.090 / 0.118$ \\
\hline $\begin{array}{c}\text { Supralinearity } \\
\text { correction applied } \\
\text { only for dose greater } \\
\text { than 1,000 rad }\end{array}$ & $-0.039 / 0.071$ & $-0.001 / 0.100$ & $-0.028 / 0.081$ \\
\hline
\end{tabular}

\section{SUMMARY}

Light attenuating filters are an essential component for dosimetry programs providing LiF TLD nuclear accident dosimetry. Attenuation filters reduce the light transmitted from TLDs after high doses of radiation, preventing PMT damage and loss of signal. This experiment demonstrates that acceptable dosimetry results can be obtained using light attenuation filters if an appropriate calibration procedure is employed. A problem with the current calibration procedure was discovered when processing dosimeters with a $1 \%$ transmission filter.

The current procedure calls for calibration of the reader using routine calibration cards with the filters installed. The filters reduced the calibration signal to a level at which PMT noise became significant. The element 3 PMT noise from reader 11 calibrated with a $1 \%$ filter comprised approximately $30 \%$ of the calibration signal. This caused the recorded response of element 3 to be about $30 \%$ low. The net effect of low element 3 readings was that $L 3 / L 1$ and $L 3 / L 2$ ratios were below values expected for high energy photons by the dose assessment algorithm. The low ratios adversely affected the dose calculation, resulting in a much lower than actual reported dose.

The low reported dose resulted in failure to achieve the performance requirements of DOE 5480.11 for nuclear accident dosimetry using reader 11 with a $1 \%$ transmission filter. Results obtained with a $1 \%$ filter using reader 55 , and from other element readings 
with reader 11 , demonstrate the performance requirements can be achieved if the system is properly calibrated.

The current PMT noise specifications are acceptable under routine conditions, but become a problem when using a $1 \%$ transmission filter. io avoid this problem the calibration signal can be increased, filters may be inserted after routine calibration, or the PMT noise can be subtracted during the calibration procedure. Problems exist with all methods. If the calibration signal is increased, calibration cards will have to be maintained at all times which have been exposed to relatively high doses. High doses will lead to degradation in card response and a high turnover of calibration cards. Inserting filters after the calibration has been performed may affect the calibration, and subtraction of the PMT noise from calibration results using the $1 \%$ filter could affect the statistics associated with the signal response.

The dose assessment algorithm used by CEDS includes a supralinearity correction which starts to take effect with doses greater than 100 rad. The correction applied is a function of the reported dose. Based on the results of this study, the supralinearity correction used for calculating dose is greater than that observed over some dose ranges. When the correction was applied for doses between 100 and $1,000 \mathrm{rad}$, the performance of the dosimetry system suffered. At this time there is no supralinearity correction in CEDS procedures for doses greater than 1,000 rad. In the event of an accident resulting in exposures at this level, our documentation would not support calculation of doses. For this report, the supralinearity correction used for doses between 400 and 1,000 rad was ext эnded for dosimeters irradiated greater than or equal to 5,000 rad with acceptable results.

\section{FUTURE WORK}

This study, though limited in scale, indicated a need for more work in two areas. The calibration failure of reader 11 with a $1 \%$ transmission filter demonstrated that otherwise acceptable background noise can be excessive in some cases. Although use of a $1 \%$ transmission filter is an unusual event, a need for change in the calibration procedure is indicated. The supralinearity correction should be investigated to determine 
if changes are necessary for doses greater than or equal to 100 rad. In addition, CEDS procedures or the dose assessment algorithm should be updated to allow for supralinearity correction of doses greater than 1,000 rad.

\section{REFERENCES}

1. CEDS Procedure 3-1-500, Rev. 3, "Personnel Nuclear Accident Dosimetry," Centralized External Dosimetry System Standard Operating Procedures and Quality Assurance Program Manual, Martin Marietta Energy Systems, Inc., Oak Ridge, Tenn., March 1993.

2. M. Moscovitch, G. Bencke, and B. Wilder, Dose Calculation Algorithm for the Department of Energy Laboratory Accreditation Program, Engelhard Corporation, Harshaw Crystal and Electronic Products, Solon, Ohio, June 1989.

3. Department of Energy Standard for the Performance Testing of Personnel Dosimetry Systems, DOE/EH-0027, U.S. Department of Energy, 1986.

4. E. Piesch, B. Burgkhardt, and S. Kabadjova, "Supralinearity and Re-Evaluation of Different LiF Dosimeter Types," Nucl. Instruments and Methods 126, 563 (1975).

5. B. Burgkhardt, E. Piesch, and D. Sigh, "High-Dose Characteristic of $\mathrm{LiF}$ and $\mathrm{Li}_{2}$ $B_{4}$ 0, Thermoluminescent Dosimeters," Nucl. Instruments and Methods 148, 613 (1978).

6. Radiation Protection for Occupational Workers, DOE 5480.11, U.S. Department of Energy, 1988. 
Appendix A

DATA TABLES 
Stop Cases 9a, 10b chosen

\begin{tabular}{|c|c|c|c|c|c|c|c|}
\hline \multirow[b]{2}{*}{$\begin{array}{l}\text { HBG } \\
\text { No. }\end{array}$} & \multirow[b]{2}{*}{ PC } & \multirow[b]{2}{*}{$\begin{array}{l}\text { Del. H } \\
\text { (RAD) }\end{array}$} & \multirow[b]{2}{*}{$\begin{array}{l}\text { Step } \\
\text { Case }\end{array}$} & \multicolumn{4}{|c|}{ Uncorrected Dose (REN) } \\
\hline & & & & $\begin{array}{l}\text { Rep. } \\
\text { Hd }\end{array}$ & $\begin{array}{l}\text { Rep. } \\
\text { Hs }\end{array}$ & $\begin{array}{l}P Q \\
\text { Hd }\end{array}$ & $\begin{array}{l}P Q \\
\text { Hs }\end{array}$ \\
\hline $\begin{array}{l}63192 \\
69357 \\
163171 \\
120347 \\
148334 \\
125810\end{array}$ & $\begin{array}{l}\text { ORNL } \\
\text { ORNL } \\
\text { ORNL } \\
Y-12 \\
Y-12 \\
Y-12\end{array}$ & $\begin{array}{l}0.500 \\
0.500 \\
0.500 \\
0.500 \\
0.500 \\
0.500\end{array}$ & $\begin{array}{c}12 \\
10 b \\
9 a \\
9 a \\
9 a \\
9 a\end{array}$ & $\begin{array}{l}0.318 \\
0.458 \\
0.537 \\
0.560 \\
0.558 \\
0.554\end{array}$ & $\begin{array}{l}0.320 \\
0.565 \\
0.534 \\
0.505 \\
0.556 \\
0.555\end{array}$ & $\begin{array}{r}-0.362 \\
-0.084 \\
0.074 \\
0.119 \\
0.113 \\
0.107\end{array}$ & $\begin{array}{c}-0.361 \\
0.130 \\
0.069 \\
0.011 \\
0.113 \\
0.110\end{array}$ \\
\hline $\begin{array}{l}101848 \\
115243\end{array}$ & $\begin{array}{l}\text { ORNL } \\
\text { ORNL }\end{array}$ & $\begin{array}{l}1.000 \\
1.000\end{array}$ & $\begin{array}{l}9 a \\
8 a\end{array}$ & $\begin{array}{l}0.985 \\
1.049\end{array}$ & $\begin{array}{l}0.842 \\
0.807\end{array}$ & & $\begin{array}{r}-0.158 \\
-0.093\end{array}$ \\
\hline 403935 & ORNL & 1.000 & $\mathbf{9 a}$ & 1.062 & 0.935 & 0.062 & -0.085 \\
\hline 122005 & $Y-12$ & 1.000 & 12 & 0.594 & 0.644 & -0.408 & -0.356 \\
\hline 120084 & $Y-12$ & 1.000 & $\mathbf{9 a}$ & 1.006 & 0.858 & 0.006 & -0.042 \\
\hline 164108 & $Y-12$ & 1.000 & $\mathbf{9 a}$ & 1.031 & 0.971 & 0.031 & -0.029 \\
\hline 164158 & ORNL & 10 & 12 & 6.68 & 3.91 & -0.332 & -0.609 \\
\hline 163084 & ORNL & 10 & 12 & 6.60 & 4.49 & -0.340 & -0.551 \\
\hline 18805 & ORNL & 10 & $\mathbf{9 a}$ & 9.48 & 6.88 & -0.052 & -0.312 \\
\hline 722225 & $Y-12$ & 10 & 98 & 10.44 & 8.46 & 0.044 & -0.154 \\
\hline 16862 & $Y-12$ & 10 & 88 & 9.35 & 8.88 & -0.065 & -0.102 \\
\hline 134996 & $Y-12$ & 10 & $9 a$ & 9.54 & 9.24 & -0.046 & -0.076 \\
\hline 109374 & ORNL & $\mathbf{5 0}$ & 12 & 35.93 & 20.13 & -0.281 & -0.597 \\
\hline 131712 & ORNL & 50 & 12 & 34.71 & 19.62 & -0.306 & -0.608 \\
\hline 183625 & ORNL & 50 & 12 & 38.13 & 22.26 & -0.277 & -0.555 \\
\hline 178418 & $Y-12$ & 50 & $\mathbf{9 a}$ & 52.57 & 42.97 & 0.051 & -0.141 \\
\hline 113169 & $Y-12$ & 50 & $9 \mathbf{a}$ & 51.70 & 42.66 & 0.034 & -0.147 \\
\hline 0 & $Y-12$ & 50 & $\mathbf{9 a}$ & 52.11 & 46.75 & 0.042 & -0.065 \\
\hline
\end{tabular}

Fade Cormected Dose (REM)

Rep. Rep. PQ PQ

Hd Hs Hd Hs

$\begin{array}{lllll}0.318 & 0.319 & -0.364 & -0.363\end{array}$

$\begin{array}{llll}0.457 & 0.563 & -0.087 & 0.126\end{array}$

$\begin{array}{lllll}0.535 & 0.635 & 0.070 & 0.070\end{array}$

$\begin{array}{|llll|}0.558 & 0.680 & 0.115 & 0.116\end{array}$

$\begin{array}{llll}0.554 & 0.555 & 0.109 & 0.108\end{array}$

$\begin{array}{lllll}0.552 & 0.553 & 0.104 & 0.107\end{array}$

$\begin{array}{llll}0.962 & 0.962 & -0.038 & -0.038\end{array}$

$\begin{array}{llll}1.045 & 1.045 & 0.045 & 0.045\end{array}$

$\begin{array}{llll}1.058 & 1.068 & 0.058 & 0.068\end{array}$

$\begin{array}{llll}0.592 & 0.642 & -0.408 & -0.358\end{array}$

$\begin{array}{llll}1.002 & 1.002 & 0.002 & 0.002\end{array}$

$\begin{array}{lllll}1.028 & 1.028 & 0.028 & 0.028\end{array}$

$\begin{array}{lllll}6.66 & 6.66 & -0.334 & -0.334\end{array}$

$\begin{array}{lllll}6.57 & 6.57 & -0.343 & -0.343\end{array}$

$\begin{array}{lllll}9.45 & 9.45 & -0.055 & -0.065\end{array}$

$\begin{array}{lllll}10.40 & 10.40 & 0.040 & 0.040\end{array}$

$\begin{array}{lllll}9.32 & 9.32 & -0.068 & -0.068\end{array}$

$\begin{array}{llll}9.51 & 9.51 & -0.049 & -0.049\end{array}$

$\begin{array}{lllll}35.81 & 35.81 & -0.284 & -0.284\end{array}$

$\begin{array}{lllll}34.59 & 34.69 & -0.308 & -0.308\end{array}$

$\begin{array}{lllll}36.02 & 36.02 & -0.280 & -0.280\end{array}$

$\begin{array}{lllll}52.39 & 52.39 & 0.048 & 0.048\end{array}$

$\begin{array}{llll}51.53 & 51.53 & 0.031 & 0.031\end{array}$

$\begin{array}{llll}51.94 & 51.94 & 0.039 & 0.039\end{array}$
Final Reported Dose (REM)

\begin{tabular}{ccc} 
Supralinaarity (SL) Correctad \\
\hline Rep. Rep. PQ PQ
\end{tabular}

\begin{tabular}{|c|c|c|c|}
\hline Hd & is. & Hd & Hs \\
\hline $\begin{array}{l}7 \\
5 \\
8 \\
4 \\
2\end{array}$ & $\begin{array}{l}0.319 \\
0.563 \\
0.536 \\
0.568 \\
0.555 \\
0.553\end{array}$ & $\begin{array}{c}-0.364 \\
-0.087 \\
0.070 \\
0.115 \\
0.109 \\
0.104\end{array}$ & $\begin{array}{c}-0.363 \\
0.126 \\
0.070 \\
0.115 \\
0.109 \\
0.107\end{array}$ \\
\hline $\begin{array}{l}862 \\
045\end{array}$ & $\begin{array}{l}0.562 \\
1.046\end{array}$ & & \\
\hline & 1.068 & & \\
\hline & 0.642 & & \\
\hline .00 & & & \\
\hline 1.02 & 1.028 & & \\
\hline 6.6 & & -0.3 & \\
\hline 6.5 & & -0.3 & -0.8 \\
\hline 8.4 & & -0.0 & \\
\hline 10.40 & 10.40 & 0.040 & 0.04 \\
\hline 9.3 & 9.32 & -0.068 & -0.068 \\
\hline $\begin{array}{c}9.51 \\
35.81\end{array}$ & $\begin{array}{c}9.61 \\
35.81\end{array}$ & $\begin{array}{l}-0.049 \\
-0.284\end{array}$ & $\begin{array}{l}-0.049 \\
-0.284\end{array}$ \\
\hline & 34.69 & -0.308 & -0.308 \\
\hline & & -0.280 & -0.28 \\
\hline & 52. & 0.048 & 0.04 \\
\hline & & & \\
\hline & 51.94 & 0.039 & 0.03 \\
\hline
\end{tabular}


Step Cases 8a, 10b chosen, Continued

$\begin{array}{llll}\text { HBG } & \text { PC } & \text { Del. H } & \text { Step } \\ \text { No. } & & \text { (RAD) } & \text { Case } \\ & & & \\ 141826 & \text { ORNL } & 100 & 12 \\ 106867 & \text { ORNL } & 100 & 12 \\ 112514 & \text { ORNL } & 100 & 12 \\ 102232 & \text { Y-12 } & 100 & 9 a \\ 169589 & \text { Y-12 } & 100 & 9 a \\ 176760 & \text { Y-12 } & 100 & 9 a \\ 106752 & \text { ORNL } & 500 & 12 \\ 141637 & \text { ORNL } & 500 & 12 \\ 135744 & \text { ORNL } & 500 & 9 a \\ 145458 & \text { Y-12 } & 500 & 12 \\ 160239 & \text { Y-12 } & 500 & 9 a \\ 175433 & \text { Y-12 } & 500 & 9 a \\ 133138 & \text { ORNL } & 1000 & 12 \\ 115883 & \text { ORNL } & 1000 & 12 \\ 101980 & \text { ORNL } & 1000 & 9 a \\ 128334 & \text { Y-12 } & 1000 & 12 \\ 114575 & \text { Y-12 } & 1000 & 12 \\ 177226 & \text { Y-12 } & 1000 & 9 a \\ 167861 & \text { ORNL } & 5000 & 12 \\ 167309 & \text { ORNL } & 5000 & 12 \\ 112841 & \text { ORNL } & 5000 & 9 a \\ 170445 & \text { Y-12 } & 5000 & 12 \\ 130213 & \text { Y-12 } & 5000 & 12 \\ 131453 & \text { Y-12 } & 5000 & 9 a \\ 109498 & \text { ORNL } & 10000 & 12 \\ 140551 & \text { ORNL } & 10000 & 12 \\ 163950 & \text { ORNL } & 10000 & 12 \\ 170459 & \text { Y-12 } & 10000 & 9 a \\ 124196 & \text { Y-12 } & 10000 & 9 a \\ 100290 & \text { Y-12 } & 10000 & 9 a\end{array}$

Uncorrected Dose (H)

\begin{tabular}{|c|c|c|c|}
\hline $\begin{array}{l}\text { Rep. } \\
\text { Hd }\end{array}$ & $\begin{array}{c}\text { Rep. } \\
\text { its }\end{array}$ & $\begin{array}{l}P Q \\
H d\end{array}$ & $\begin{array}{l}P Q \\
\text { Hs }\end{array}$ \\
\hline 63.66 & 37.01 & -0.363 & -0.630 \\
\hline 67.51 & 41.55 & -0.325 & -0.585 \\
\hline 70.92 & 38.34 & -0.291 & -0.617 \\
\hline 104 & 87 & 0.038 & -0.128 \\
\hline 103 & 87 & 0.034 & -0.135 \\
\hline 108 & 93 & 0.079 & -0.074 \\
\hline 341 & 230 & -0.319 & -0.540 \\
\hline $\begin{array}{l}338 \\
514\end{array}$ & $\begin{array}{l}238 \\
390\end{array}$ & $\begin{array}{c}-0.324 \\
0.028\end{array}$ & $\begin{array}{l}-0.524 \\
-0.220\end{array}$ \\
\hline $\begin{array}{l}514 \\
347\end{array}$ & 341 & -0.306 & -0.318 \\
\hline 608 & 495 & 0.216 & -0.010 \\
\hline 580 & 550 & 0.180 & 0.100 \\
\hline 742 & 532 & -0.258 & -0.468 \\
\hline 716 & 513 & -0.284 & -0.487 \\
\hline 1132 & 814 & 0.132 & -0.186 \\
\hline 688 & 702 & -0.304 & -0.298 \\
\hline 777 & 749 & -0.223 & -0.251 \\
\hline 1200 & 1155 & 0.200 & 0.155 \\
\hline 6081 & 3834 & 0.216 & -0.233 \\
\hline 5807 & 4356 & 0.161 & -0.129 \\
\hline 8681 & 6052 & 0.736 & 0.210 \\
\hline 5586 & 5200 & 0.113 & 0.042 \\
\hline 5197 & 4483 & 0.039 & -0.103 \\
\hline 10215 & 8871 & 1.043 & 0.774 \\
\hline 12953 & 7836 & 0.295 & -0.216 \\
\hline 16193 & 8965 & 0.619 & -0.104 \\
\hline 14344 & 8369 & 0.434 & -0.163 \\
\hline 22251 & 20512 & 1.225 & 1.051 \\
\hline 26287 & 22314 & 1.629 & 1.231 \\
\hline 18653 & 17291 & 0.865 & 0.729 \\
\hline
\end{tabular}

Fade Corrected Dose

$\begin{array}{cccc}\text { Rep. } & \text { Rep. } & \text { PQ } & \text { PQ } \\ \text { Hd } & \text { Hs } & \text { Hd } & \text { Hs }\end{array}$

$\begin{array}{llll}63 & 63 & -0.365 & -0.365\end{array}$

$\begin{array}{llll}67 & 67 & -0.327 & -0.327 \\ 71 & 71 & -0.293 & -0.293\end{array}$

$\begin{array}{llll}71 & 71 & -0.293 & -0.293\end{array}$

$\begin{array}{llll}103 & 103 & 0.034 & 0.034\end{array}$

$\begin{array}{llll}103 & 103 & 0.031 & 0.031\end{array}$

$\begin{array}{llll}108 & 108 & 0.075 & 0.075\end{array}$

$\begin{array}{llll}340 & 340 & -0.321 & -0.321\end{array}$

$\begin{array}{llll}337 & 337 & -0.326 & -0.326\end{array}$

$\begin{array}{llll}512 & 512 & 0.025 & 0.025\end{array}$

$\begin{array}{llll}346 & 346 & -0.308 & -0.308\end{array}$

$\begin{array}{llll}606 & 606 & 0.212 & 0.212\end{array}$

$\begin{array}{llll}588 & 588 & 0.176 & 0.176\end{array}$

$\begin{array}{llll}740 & 740 & -0.260 & -0.260\end{array}$

$\begin{array}{llll}713 & 713 & -0.287 & -0.287\end{array}$

$\begin{array}{llll}1129 & 1129 & 0.129 & 0.129\end{array}$

$\begin{array}{lllll}693 & 700 & -0.307 & -0.300\end{array}$

$\begin{array}{llll}774 & 774 & -0.226 & -0.226\end{array}$

$\begin{array}{llll}1198 & 1196 & 0.186 & 0.196\end{array}$

$\begin{array}{llll}6081 & \operatorname{cos1} & 0.212 & 0.212\end{array}$

$\begin{array}{lllll}5788 & 5788 & 0.158 & 0.168\end{array}$

$\begin{array}{llll}8653 & 8653 & 0.731 & 0.731\end{array}$

$\begin{array}{llll}5548 & 5648 & 0.110 & 0.110\end{array}$

$\begin{array}{llll}5180 & 5180 & 0.036 & 0.036\end{array}$

$\begin{array}{llll}10181 & 10181 & 1.036 & 1.036\end{array}$

$\begin{array}{lllll}12910 & 12910 & 0.291 & 0.291\end{array}$

\begin{tabular}{llll|}
16139 & 16139 & 0.614 & 0.614
\end{tabular}

$\begin{array}{lllll}14297 & 14297 & 0.430 & 0.430\end{array}$

$\begin{array}{llll}22178 & 22178 & 1.218 & 1.218\end{array}$

$\begin{array}{llll}26201 & 26201 & 1.620 & 1.620\end{array}$

$\begin{array}{llll}18592 & 18592 & 0.859 & 0.859\end{array}$
Final Reported Dose

Supralinaarity (SL) Corrected

$\begin{array}{ccc}\text { Rep. Rep. PQ PQ } & \end{array}$

Hd Hs Hd Hs

$\begin{array}{llll}63 & 63 & -0.365 & -0.365\end{array}$

$\begin{array}{llll}67 & 67 & -0.327 & -0.327\end{array}$

$\begin{array}{llll}71 & 71 & -0.293 & -0.293\end{array}$

$99 \quad 99 \quad-0.015 \quad-0.015$

$\begin{array}{llll}98 & 98 & -0.018 & -0.018\end{array}$

$\begin{array}{lllll}102 & 102 & 0.024 & 0.024\end{array}$

$\begin{array}{llll}267 & 267 & -0.466 & -0.466\end{array}$

$\begin{array}{lllll}266 & 268 & -0.469 & -0.469\end{array}$

$\begin{array}{llll}382 & 455 & -0.236 & -0.091\end{array}$

$\begin{array}{llll}270 & 270 & -0.459 & -0.459\end{array}$

$\begin{array}{llll}446 & 536 & -0.109 & 0.071\end{array}$

$\begin{array}{llll}434 & 520 & -0.133 & 0.040\end{array}$

$\begin{array}{llll}535 & 652 & -0.465 & -0.348\end{array}$

$\begin{array}{llll}518 & 629 & -0.482 & -0.371\end{array}$

$\begin{array}{lllll}788 & 986 & -0.212 & -0.014\end{array}$

$\begin{array}{llll}504 & 617 & -0.496 & -0.383\end{array}$

$\begin{array}{llll}558 & 681 & -0.442 & -0.319\end{array}$

$\begin{array}{llll}831 & 1043 & -0.169 & 0.043\end{array}$

$\begin{array}{llll}3652 & 5107 & -0.270 & 0.021\end{array}$

$\begin{array}{llll}3502 & 4882 & -0.300 & -0.024\end{array}$

$\begin{array}{llll}5048 & 7233 & 0.010 & 0.447\end{array}$

$\begin{array}{lllll}3369 & 4684 & -0.326 & -0.063\end{array}$

$\begin{array}{llll}3165 & 4379 & -0.367 & -0.124\end{array}$

$\begin{array}{lllll}5853 & 8480 & 0.171 & 0.686\end{array}$

$\begin{array}{lllll}7262 & 10695 & -0.274 & 0.069\end{array}$

$\begin{array}{llll}8895 & 13301 & -0.110 & 0.330\end{array}$

$\begin{array}{llll}7968 & 11815 & -0.203 & 0.182\end{array}$

$\begin{array}{lllll}11873 & 18143 & 0.187 & 0.814\end{array}$

$\begin{array}{lllll}13813 & 21350 & 0.381 & 1.135\end{array}$

$\begin{array}{llll}10115 & 15272 & 0.012 & 0.527\end{array}$ 
Cs-137 Exposures Processed with 18 Transeission Filter

Step Cases 12, Ic, $10 c$ chosen.

\begin{tabular}{|c|c|c|c|c|c|c|c|c|c|c|c|}
\hline \multirow[b]{2}{*}{$\begin{array}{l}\text { HBG } \\
\text { No. }\end{array}$} & \multirow[b]{2}{*}{ PC } & \multirow[b]{2}{*}{$\begin{array}{l}\text { Del. H } \\
\text { (RAD) }\end{array}$} & \multirow[b]{2}{*}{$\begin{array}{l}\text { Step } \\
\text { Case }\end{array}$} & \multicolumn{4}{|c|}{ Uncomected Does (H) } & \multicolumn{4}{|c|}{ rede Collocide Dos: } \\
\hline & & & & $\begin{array}{l}\text { Rep. } \\
\text { Hd }\end{array}$ & $\begin{array}{c}\text { Rep. } \\
\text { Hs }\end{array}$ & $\begin{array}{l}\text { PQ } \\
\text { Hd }\end{array}$ & $\begin{array}{l}\mathrm{PQ} \\
\mathrm{Hs}\end{array}$ & $\begin{array}{l}\text { Rep. } \\
\text { Hd }\end{array}$ & $\begin{array}{c}\text { Rep. } \\
\text { Hs }\end{array}$ & $\begin{array}{l}P Q \\
\text { Hd }\end{array}$ & $\begin{array}{l}\mathrm{PQ} \\
\mathrm{HS}\end{array}$ \\
\hline 69357 & $x-10$ & 0.500 & $10 c$ & 0.458 & 0.683 & -0.084 & 0.328 & 0.457 & 0.661 & -0.087 & 0.322 \\
\hline 63192 & $x-10$ & 0.500 & 12 & 0.318 & 0.320 & -0.362 & -0.381 & 0.318 & 0.319 & -0.384 & -0.363 \\
\hline 63171 & $x-10$ & 0.500 & $8 c$ & 0.485 & 0.475 & -0.030 & -0.050 & 0.483 & 0.483 & -0.034 & -0.034 \\
\hline 20347 & $Y-12$ & 0.500 & 9c & 0.505 & 0.449 & 0.011 & -0.101 & 0.504 & 0.504 & 0.007 & 0.007 \\
\hline 48334 & $Y-12$ & 0.500 & $8 c$ & 0.502 & 0.495 & 0.005 & -0.011 & 0.501 & 0.601 & 0.002 & 0.002 \\
\hline 125810 & $Y-12$ & 0.500 & Sc & 0.500 & & & & & 0.498 & $\begin{array}{l}-0.003 \\
-0.131\end{array}$ & $\begin{array}{r}-0.003 \\
-1.131\end{array}$ \\
\hline $\begin{array}{l}101848 \\
115243\end{array}$ & $\begin{array}{l}x-10 \\
x-10\end{array}$ & $\begin{array}{l}1.000 \\
1.000\end{array}$ & $\begin{array}{l}8 c \\
8 c\end{array}$ & $\begin{array}{l}0.872 \\
0.947\end{array}$ & $\begin{array}{l}0.749 \\
0.806\end{array}$ & $\begin{array}{l}-0.128 \\
-0.053\end{array}$ & $\begin{array}{l}-0.251 \\
-0.184\end{array}$ & $\begin{array}{l}0.889 \\
0.844\end{array}$ & $\begin{array}{l}0.809 \\
0.844\end{array}$ & $\begin{array}{l}-0.131 \\
-0.056\end{array}$ & $\begin{array}{l}-0.131 \\
-0.056\end{array}$ \\
\hline 103935 & $x-10$ & 1.000 & gc & 0.959 & 0.831 & -0.041 & -0.169 & 0.956 & 0.968 & -0.044 & -0.044 \\
\hline 122005 & $Y-12$ & 1.000 & 12 & 0.584 & 0.644 & -0.406 & -0.358 & 0.592 & 0.642 & -0.408 & -0.358 \\
\hline 120084 & $Y-12$ & 1.000 & $8 c$ & 0.908 & 0.851 & -0.092 & -0.149 & 0.805 & 0.805 & -0.095 & -0.085 \\
\hline 164108 & $Y-12$ & 1.000 & sc & 0.931 & 0.863 & -0.089 & -0.137 & 0.928 & 0.928 & -0.072 & -0.072 \\
\hline 164158 & $x-10$ & 10 & 12 & 6.68 & 3.91 & -0.332 & -0.609 & 6.66 & 6.68 & -0.334 & -0.334 \\
\hline 163064 & $x-10$ & 10 & 12 & 6.60 & 4.49 & -0.340 & -0.551 & 6.57 & 6.67 & -0.343 & -0.343 \\
\hline 118605 & $x-10$ & 10 & Sc & 8.58 & 6.12 & -0.144 & -0.388 & 8.53 & 8.63 & -0.147 & -0.147 \\
\hline 172225 & $Y-12$ & 10 & sc & 9.43 & 7.52 & -0.057 & -0.248 & 9.40 & 9.40 & -0.060 & -0.060 \\
\hline 116862 & $Y-12$ & 10 & $8 c$ & 8.44 & 7.88 & -0.156 & -0.202 & 8.41 & 8.41 & -0.159 & -0.169 \\
\hline 134986 & $Y-12$ & 10 & 8c & 8.61 & 8.22 & -0.139 & -0.178 & 8.59 & 8.59 & -0.141 & -0.141 \\
\hline 109374 & $x-10$ & 50 & 12 & 35.93 & 20.13 & -0.281 & -0.597 & 35.81 & 35.81 & -0.284 & -0.284 \\
\hline 131712 & $x-10$ & 50 & 12 & 34.71 & 19.62 & -0.306 & -0.608 & 34.59 & 34.69 & -0.308 & -0.308 \\
\hline 183625 & $x-10$ & 50 & 12 & 36.13 & 22.26 & -0.277 & -0.555 & 36.02 & 36.02 & -0.280 & -0.280 \\
\hline 178419 & $Y-12$ & 50 & 8c & 47.47 & 38.20 & -0.051 & -0.236 & 47.32 & 47.32 & -0.054 & -0.054 \\
\hline 113169 & $Y-12$ & 50 & gc & 46.69 & 37.93 & -0.066 & -0.241 , & 46.54 & 46.54 & -0.069 & -0.069 \\
\hline 148557 & $Y-12$ & 50 & $8 c$ & 47.06 & 41.56 & -0.059 & -0.169 & 46.91 & 46.91 & -0.062 & -0.062 \\
\hline
\end{tabular}

Final Reported Dose

Suprolinaarity (SL) Corrected

\begin{tabular}{|c|c|c|c|}
\hline $\begin{array}{l}\text { Rep. } \\
\text { Hd }\end{array}$ & $\begin{array}{l}\text { Rep. } \\
\text { Hs }\end{array}$ & $\begin{array}{l}P Q \\
\text { Hd }\end{array}$ & $\begin{array}{l}P Q \\
\text { Hs }\end{array}$ \\
\hline 0.457 & 0.661 & -0.087 & 0.322 \\
\hline 0.318 & 0.319 & -0.364 & -0.363 \\
\hline 0.483 & 0.483 & -0.034 & -0.034 \\
\hline $\begin{array}{l}0.504 \\
0.501\end{array}$ & $\begin{array}{l}0.504 \\
0.601\end{array}$ & $\begin{array}{l}0.007 \\
0.002\end{array}$ & $\begin{array}{l}0.007 \\
0.002\end{array}$ \\
\hline 0.498 & 0.498 & -0.003 & -0.003 \\
\hline $\begin{array}{l}0.869 \\
0.944\end{array}$ & $\begin{array}{l}0.869 \\
0.944\end{array}$ & $\begin{array}{l}-0.131 \\
-0.056\end{array}$ & $\begin{array}{l}-0.131 \\
-0.056\end{array}$ \\
\hline 0.956 & 0.958 & -0.044 & -0.044 \\
\hline 0.592 & 0.642 & -0.408 & -0.358 \\
\hline 0.905 & 0.206 & -0.095 & -0.095 \\
\hline 0.928 & 0.928 & -0.072 & -0.072 \\
\hline 6.66 & 6.66 & -0.334 & -0.334 \\
\hline 6.57 & 6.57 & -0.343 & -0.343 \\
\hline 8.53 & 8.53 & -0.147 & -0.147 \\
\hline 9.40 & 9.40 & -0.060 & -0.060 \\
\hline 8.41 & 8.41 & -0.159 & -0.159 \\
\hline 8.59 & 8.59 & -0.141 & -0.141 \\
\hline 35.81 & 35.81 & -0.284 & -0.284 \\
\hline 34.59 & 34.59 & -0.308 & -0.308 \\
\hline 36.02 & 36.02 & -0.280 & -0.280 \\
\hline 47.32 & 47.32 & -0.054 & -0.054 \\
\hline 46.54 & 46.54 & -0.069 & -0.069 \\
\hline 46.9 & 46.91 & -0.062 & -0.062 \\
\hline
\end{tabular}


Step Cases 12, sc, $10 c$ chosen, Continued.

\begin{tabular}{|c|c|c|c|c|c|c|c|c|c|c|c|c|c|c|c|}
\hline \multirow[b]{2}{*}{$\begin{array}{l}\text { HBG } \\
\text { No. }\end{array}$} & \multirow[b]{2}{*}{ PC } & \multirow[b]{2}{*}{$\begin{array}{l}\text { Del. H } \\
\text { (RAD) }\end{array}$} & \multirow[b]{2}{*}{$\begin{array}{l}\text { Step } \\
\text { Case }\end{array}$} & \multicolumn{4}{|c|}{ Uncorrected Dose (H) } & \multicolumn{4}{|c|}{ Fade Corrected Dose } & \multicolumn{4}{|c|}{ Supralinearity (SL) Corrected } \\
\hline & & & & $\begin{array}{c}\text { Rep. } \\
\text { Hd }\end{array}$ & $\begin{array}{c}\text { Rep. } \\
\text { Hs }\end{array}$ & $\begin{array}{l}P Q \\
\text { Hd }\end{array}$ & $\begin{array}{l}P Q \\
H s\end{array}$ & $\begin{array}{c}\text { Rep. } \\
\text { Hd }\end{array}$ & $\begin{array}{l}\text { Rep. } \\
\text { Hs }\end{array}$ & $\begin{array}{l}P Q \\
\text { Hd }\end{array}$ & $\begin{array}{l}\mathbf{P Q} \\
\text { Hs }\end{array}$ & $\begin{array}{l}\text { Rep. } \\
\text { Hd }\end{array}$ & $\begin{array}{c}\text { Rep. } \\
\text { Hs }\end{array}$ & $\begin{array}{l}P Q \\
H d\end{array}$ & $\begin{array}{l}P Q \\
\text { Hs }\end{array}$ \\
\hline 141826 & $x-10$ & 100 & 12 & 64 & 37 & -0.363 & -0.630 & 63 & 63 & -0.365 & -0.365 & 63 & 63 & -0.385 & -0.365 \\
\hline 106867 & $x-10$ & 100 & 12 & 68 & 42 & -0.325 & -0.5 & 67 & 67 & -0.327 & -0.327 & 67 & 67 & -0.327 & -0.327 \\
\hline 112514 & $x-10$ & 100 & 12 & 71 & 38 & -0.291 & -0.617 & 71 & 71 & -0.293 & -0.293 & 71 & 71 & -0.293 & -0.293 \\
\hline 102232 & $Y-12$ & 100 & $9 c$ & 94 & 78 & -0.063 & -0.223 & 93 & 93 & -0.068 & -0.066 & 93 & 93 & -0.066 & -0.068 \\
\hline 169589 & $Y-12$ & 100 & gc & 93 & 77 & -0.066 & -0.231 & 93 & 93 & -0.069 & -0.069 & 93 & 93 & -0.069 & -0.069 \\
\hline 176760 & $Y-12$ & 100 & 9c & 97 & 82 & -0.026 & -0.176 & 87 & 97 & -0.029 & -0.029 & 97 & 97 & -0.029 & -0.029 \\
\hline 106752 & $x-10$ & 500 & 12 & 341 & 230 & -0.319 & -0.540 & 340 & 340 & -0.321 & -0.321 & 267 & 267 & -0.468 & -0.466 \\
\hline 141637 & $x-10$ & 500 & 12 & 338 & 238 & -0.324 & -0.524 & 337 & 337 & -0.326 & -0.326 & 266 & 266 & -0.469 & -0.469 \\
\hline 135744 & $x-10$ & 500 & sc & 464 & 347 & -0.071 & -0.307 & 463 & 463 & -0.074 & -0.074 & 348 & 411 & -0.304 & -0.177 \\
\hline 145458 & $Y-12$ & 500 & 12 & 347 & 341 & -0.306 & -0.318 & 346 & 346 & -0.308 & -0.308 & 270 & 270 & -0.459 & -0.459 \\
\hline 160239 & $Y-12$ & 500 & $9 c$ & 549 & 440 & 0.098 & -0.120 & 547 & 547 & 0.094 & 0.084 & 406 & 485 & -0.188 & -0.030 \\
\hline 175433 & $Y-12$ & 500 & gc & 53 & 489 & 0.066 & -0.022 & 531 & 531 & 0.062 & 0.062 & 395 & 471 & -0.210 & -0.058 \\
\hline 133138 & $x-10$ & 1000 & 12 & 742 & 532 & -0.258 & -0.468 & 740 & 740 & -0.260 & -0.260 & 535 & 652 & -0.465 & -0.348 \\
\hline 115883 & $x-10$ & 1000 & 12 & 716 & 513 & -0.284 & -0.487 & 713 & 713 & -0.287 & -0.287 & 518 & 629 & -0.482 & -0.371 \\
\hline 101960 & $x-10$ & 1000 & $9 c$ & 1023 & 724 & 0.023 & -0.276 & 1019 & 1019 & 0.019 & 0.019 & 718 & 892 & -0.282 & -0.108 \\
\hline 128334 & $Y-12$ & 1000 & 12 & 696 & 702 & -0.304 & -0.298 & 693 & 700 & -0.307 & -0 . & 504 & 617 & -0.496 & -0.383 \\
\hline 114575 & $Y-12$ & 1000 & 12 & 777 & 749 & -0.223 & -0.251 & 774 & 774 & -0.226 & -0.226 & 558 & 681 & -0.442 & -0.319 \\
\hline 177226 & $Y-12$ & 1000 & $9 c$ & 1083 & 1027 & 0.083 & 0.027 & 1080 & 1080 & 0.080 & 0.080 & 757 & 944 & -0.243 & -0.056 \\
\hline 167861 & $x-10$ & 5000 & 12 & 6081 & 3834 & 0.216 & -0.233 & 6061 & 6061 & 0.212 & 0.212 & 3652 & 5107 & -0.270 & 0.021 \\
\hline 167309 & $x-10$ & 5000 & 12 & 5807 & 4356 & 0.161 & -0.129 & 5788 & 5788 & 0.158 & 0.158 & 3502 & 4882 & -0.300 & -0.024 \\
\hline 112841 & $x-10$ & 5000 & gc & 7841 & 5380 & 0.568 & 0.076 & 7815 & 7815 & 0.563 & 0.563 & 4601 & 6547 & -0.080 & 0.309 \\
\hline 170445 & $Y-12$ & 5000 & 12 & 5568 & 5209 & 0.113 & 0.042 & 5548 & 5648 & 0.110 & 0.110 & 3369 & 4684 & -0.326 & -0.063 \\
\hline 130213 & $Y-12$ & 5000 & 12 & 5197 & 4483 & 0.039 & -0.103 & 5180 & 5180 & 0.036 & 0.036 & 3165 & 4379 & -0.367 & -0.124 \\
\hline 131453 & $Y-12$ & 5000 & $9 c$ & 9226 & 7887 & 0.845 & 0.577 & 9195 & 9185 & 0.839 & 0.839 & 5335 & 7676 & 0.067 & 0.535 \\
\hline 109498 & $x-10$ & 10000 & 12 & 12953 & 7836 & 0.295 & -0.216 & 12910 & 12910 & 0.291 & 0.291 & 7262 & 10695 & -0.274 & 0.069 \\
\hline 140551 & $x-10$ & 10000 & 12 & 16193 & 8965 & 0.619 & -0.104 & 16139 & 16139 & 0.614 & 0.614 & 8895 & 13301 & -0.110 & 0.330 \\
\hline 163950 & $x-10$ & 10000 & 12 & 14344 & 8369 & 0.434 & -0.163 & 14297 & 14297 & 0.430 & 0.430 & 7968 & 11815 & -0.203 & 0.182 \\
\hline 170459 & $Y-12$ & 10000 & $9 c$ & 20096 & 18236 & 1.010 & 0.824 & 20030 & 20030 & 1.003 & 1.003 & 10823 & 16424 & 0.082 & 0.642 \\
\hline 124196 & $Y-12$ & 10000 & $9 c$ & 23741 & 19838 & 1.374 & 0.984 & 23663 & 23663 & 1.366 & 1.366 & 12593 & 19328 & 0.259 & 0.933 \\
\hline 100290 & $Y-12$ & 10000 & 9c & 16847 & 15372 & 0.685 & 0.537 & 16791 & 16791 & 0.679 & 0.679 & 9221 & 13825 & -0.078 & 0.383 \\
\hline
\end{tabular}


Cs-137 sxposures Procosed with 108 Trananiseion Filter

Step cases 8a, 10b, 11b chosen

\begin{tabular}{|c|c|c|c|c|c|c|c|c|c|c|c|c|c|c|c|}
\hline \multirow[b]{2}{*}{$\begin{array}{l}\text { HBG } \\
\text { No. }\end{array}$} & \multirow[b]{2}{*}{ PC } & \multirow[b]{2}{*}{$\begin{array}{l}\text { Del. H } \\
\text { (RAD) }\end{array}$} & \multirow[b]{2}{*}{$\begin{array}{l}\text { Step } \\
\text { Case }\end{array}$} & \multicolumn{4}{|c|}{ Uncorrected Dose (H) } & \multicolumn{4}{|c|}{ Fade Corrected Dose } & \multicolumn{4}{|c|}{ Supralineartity (BL) Corrected } \\
\hline & & & & $\begin{array}{l}\text { Rep. } \\
\text { Hd }\end{array}$ & $\begin{array}{l}\text { Rep. } \\
\text { Hs }\end{array}$ & $\begin{array}{l}P Q \\
\text { Hd }\end{array}$ & $\begin{array}{l}\mathbf{P Q} \\
\mathrm{Hs}\end{array}$ & $\begin{array}{l}\text { Rep. } \\
\text { Hd }\end{array}$ & $\begin{array}{c}\text { Rep. } \\
\text { Hs }\end{array}$ & $\begin{array}{l}P Q \\
\text { Hd }\end{array}$ & $\begin{array}{l}P Q \\
H s\end{array}$ & $\begin{array}{l}\text { Rep. } \\
\text { Hd }\end{array}$ & $\begin{array}{c}\text { Rep. } \\
\text { Hs }\end{array}$ & $\begin{array}{l}\mathrm{PQ} \\
\mathrm{Hd}\end{array}$ & $\begin{array}{l}P Q \\
\text { Hs }\end{array}$ \\
\hline $\begin{array}{l}110829 \\
102178 \\
121861\end{array}$ & $\begin{array}{l}x-10 \\
x-10 \\
x-10\end{array}$ & $\begin{array}{l}0.500 \\
0.500 \\
0.500\end{array}$ & $\begin{array}{l}12 \\
12 \\
8 a\end{array}$ & $\begin{array}{l}0.326 \\
0.327 \\
0.560\end{array}$ & $\begin{array}{l}0.325 \\
0.322 \\
0.572\end{array}$ & $\begin{array}{l}-0.349 \\
-0.347 \\
0.121\end{array}$ & $\begin{array}{l}-0.350 \\
-0.357 \\
0.143\end{array}$ & $\begin{array}{l}0.325 \\
0.325 \\
0.559\end{array}$ & $\begin{array}{l}0.326 \\
0.325 \\
0.570\end{array}$ & $\begin{array}{c}-0.351 \\
-0.349 \\
0.117\end{array}$ & $\begin{array}{l}-0.361 \\
-0.349 \\
0.140\end{array}$ & $\begin{array}{l}0.325 \\
0.325 \\
0.559\end{array}$ & $\begin{array}{l}0.325 \\
0.325 \\
0.570\end{array}$ & $\begin{array}{l}-0.351 \\
-0.349 \\
0.117\end{array}$ & $\begin{array}{l}-0.361 \\
-0.349 \\
0.140\end{array}$ \\
\hline $\begin{array}{l}152337 \\
121203\end{array}$ & $\begin{array}{l}Y-12 \\
Y-12\end{array}$ & $\begin{array}{l}0.500 \\
0.500\end{array}$ & $\begin{array}{c}11 b \\
8 a\end{array}$ & $\begin{array}{l}0.388 \\
0.539\end{array}$ & $\begin{array}{l}0.439 \\
0.525\end{array}$ & $\begin{array}{c}-0.225 \\
0.079\end{array}$ & $\begin{array}{c}-0.121 \\
0.049\end{array}$ & $\begin{array}{l}0.388 \\
0.538\end{array}$ & $\begin{array}{l}0.438 \\
0.638\end{array}$ & $\begin{array}{l}-0.227 \\
0.075\end{array}$ & $\begin{array}{c}-0.124 \\
0.075\end{array}$ & $\begin{array}{l}0.388 \\
0.538\end{array}$ & $\begin{array}{l}0.438 \\
0.638\end{array}$ & $\begin{array}{l}-0.227 \\
0.075\end{array}$ & $\begin{array}{c}-0.124 \\
0.076\end{array}$ \\
\hline 138927 & $Y-12$ & 0.500 & $9 \mathbf{a}$ & 0.575 & 0.571 & 0.150 & 0.142 & 0.573 & 0.673 & 0.147 & 0.147 & 0.573 & 0.673 & 0.147 & 0.147 \\
\hline $\begin{array}{c}162421 \\
110688\end{array}$ & $\begin{array}{l}x-10 \\
x-10\end{array}$ & 1.000 & $8 \mathbf{a}$ & 1.118 & 1.048 & 0.118 & 0.048 & $\begin{array}{l}1.114 \\
1.077\end{array}$ & $\begin{array}{l}1.114 \\
1.078\end{array}$ & $\begin{array}{l}0.114 \\
0.077\end{array}$ & $\begin{array}{l}0.114 \\
0.078\end{array}$ & $\begin{array}{l}1.114 \\
1.077\end{array}$ & $\begin{array}{l}1.114 \\
1.078\end{array}$ & $\begin{array}{l}0.114 \\
0.077\end{array}$ & $\begin{array}{l}0.114 \\
0.078\end{array}$ \\
\hline $\begin{array}{c}110688 \\
102972\end{array}$ & $\begin{array}{l}x-10 \\
x-10\end{array}$ & $\begin{array}{l}.000 \\
.000\end{array}$ & $8 \mathbf{a}$ & $\begin{array}{l}1.080 \\
1.101\end{array}$ & $\begin{array}{l}1.082 \\
1.118\end{array}$ & $\begin{array}{l}0.080 \\
0.101\end{array}$ & $\begin{array}{l}0.082 \\
0.118\end{array}$ & $\begin{array}{l}1.077 \\
1.097\end{array}$ & 1.114 & 0.097 & 0.114 & 1.097 & 1.114 & 0.097 & 0.114 \\
\hline $\begin{array}{l}102972 \\
125480\end{array}$ & $\begin{array}{l}X-10 \\
Y-12\end{array}$ & $\begin{array}{l}1.000 \\
1.000\end{array}$ & $\begin{array}{l}9 a \\
12\end{array}$ & $\begin{array}{l}1.101 \\
0.637\end{array}$ & 0.623 & -0.383 & -0.377 & 0.635 & 0.636 & -0.365 & -0.365 & 0.635 & 0.636 & -0.365 & -0.365 \\
\hline 151146 & $Y-12$ & 1.000 & $10 b$ & 0.805 & 1.268 & -0.095 & 0.268 & 0.902 & 1.263 & -0.098 & 0.263 & 0.902 & 1.263 & -0.098 & 0.283 \\
\hline 113507 & $Y-12$ & 1.000 & $\mathbf{9 a}$ & 1.037 & 1.046 & 0.037 & 0.046 & 1.034 & 1.043 & 0.034 & 0.043 & 1.034 & 1.043 & 0.034 & 0.043 \\
\hline 163925 & $x-10$ & 10 & $\mathbf{9 a}$ & 10.52 & 9.67 & 0.052 & -0.033 & 10.48 & 10.48 & 0.048 & 0.048 & 10.48 & 10.48 & 0.048 & 0.048 \\
\hline 160823 & $x-10$ & 10 & 8a & 10.40 & 10.30 & 0.040 & 0.030 & 10.37 & 10.37 & 0.037 & 0.037 & 10.37 & 10.37 & 0.037 & 0.037 \\
\hline 139160 & $x-10$ & 10 & $\mathbf{9 a}$ & 10.41 & 10.14 & 0.041 & 0.014 & 10.38 & 10.38 & 0.038 & 0.038 & 10.38 & 10.38 & 0.038 & 0.038 \\
\hline 106014 & $Y-12$ & 10 & $\mathbf{9 a}$ & 10.73 & 10.05 & 0.073 & 0.005 & 10.69 & 10.69 & 0.069 & 0.069 & 10.69 & 10.69 & 0.069 & 0.069 \\
\hline 175288 & $Y-12$ & 10 & $\mathbf{9 a}$ & 10.63 & 10.12 & 0.063 & 0.012 & 10.60 & 10.60 & 0.060 & 0.060 & 10.60 & 10.60 & 0.060 & 0.080 \\
\hline 127728 & $Y-12$ & 10 & $\mathbf{9 a}$ & 10.63 & 10.73 & 0.063 & 0.073 & 10.59 & 10.69 & 0.059 & 0.069 & 10.59 & 10.69 & 0.059 & 0.069 \\
\hline 122584 & $x-10$ & 50 & $9 \mathbf{a}$ & 53.09 & 46.50 & 0.062 & -0.070 & 52.91 & 82.91 & 0.058 & 0.068 & 52.91 & 52.91 & 0.058 & 0.058 \\
\hline 140479 & $x-10$ & 50 & $9 \mathbf{a}$ & 52.21 & 48.62 & 0.044 & -0.028 & 52.03 & 52.03 & 0.041 & 0.041 & 52.03 & 52.03 & 0.041 & 0.041 \\
\hline 123418 & $x-10$ & 50 & $9 \mathbf{a}$ & 52.76 & 50.57 & 0.055 & 0.011 & 52.58 & 62.68 & 0.052 & 0.062 & 52.58 & 52.58 & 0.052 & 0.052 \\
\hline 111246 & $Y-12$ & 50 & $9 a$ & 55.26 & 49.54 & 0.105 & -0.009 & 55.07 & 56.07 & 0.101 & 0.101 & 55.07 & 65.07 & 0.101 & 0.101 \\
\hline 180874 & $Y-12$ & 50 & $9 a$ & 58.65 & 52.42 & 0.173 & 0.048 & 58.46 & 88.46 & 0.169 & 0.169 & 58.46 & 58.46 & 0.169 & 0.169 \\
\hline 136361 & $Y-12$ & 50 & $9 a$ & 52.81 & 54.12 & 0.056 & 0.082 & 52.63 & 53.84 & 0.053 & 0.079 & 52.63 & 53.94 & 0.053 & 0.079 \\
\hline
\end{tabular}


Step cases 9a, 10b, 11b chosen, Continued.

\begin{tabular}{|c|c|c|c|c|c|c|c|c|c|c|c|}
\hline \multirow[b]{2}{*}{$\begin{array}{l}\text { HBG } \\
\text { No. }\end{array}$} & \multirow[b]{2}{*}{ PC } & \multirow[b]{2}{*}{$\begin{array}{l}\text { Del. H } \\
\text { (RAD) }\end{array}$} & \multirow[b]{2}{*}{$\begin{array}{l}\text { Step } \\
\text { Case }\end{array}$} & \multicolumn{4}{|c|}{ Uncorrectad Dose (H) } & \multicolumn{4}{|c|}{ Fade Corrected Dose } \\
\hline & & & & $\begin{array}{c}\text { Rep. } \\
\text { Hd }\end{array}$ & $\begin{array}{l}\text { Rep. } \\
\text { Hs }\end{array}$ & $\begin{array}{l}P Q \\
H d\end{array}$ & $\begin{array}{l}\mathbf{P Q} \\
\mathrm{HS}\end{array}$ & $\begin{array}{l}\text { Rep. } \\
\text { Hd }\end{array}$ & $\begin{array}{c}\text { Rep. } \\
\text { Hs }\end{array}$ & $\begin{array}{l}\mathrm{PQ} \\
\mathrm{Hd}\end{array}$ & $\begin{array}{l}P Q \\
H s\end{array}$ \\
\hline 139468 & $x-10$ & 100 & $8 a$ & 105 & 97 & 0.052 & $\begin{array}{r}-0.035 \\
\end{array}$ & $\begin{array}{l}105 \\
110\end{array}$ & $\begin{array}{l}105 \\
110\end{array}$ & $\begin{array}{l}0.048 \\
0.102\end{array}$ & $\begin{array}{l}0.048 \\
0.102\end{array}$ \\
\hline $\begin{array}{l}164234 \\
163583\end{array}$ & $\begin{array}{l}x-10 \\
x-10\end{array}$ & $\begin{array}{l}100 \\
100\end{array}$ & $\begin{array}{l}9 a \\
9 a\end{array}$ & $\begin{array}{l}111 \\
107\end{array}$ & $\begin{array}{c}86 \\
100\end{array}$ & $\begin{array}{l}0.105 \\
0.069\end{array}$ & $\begin{array}{r}-0.042 \\
-0.004\end{array}$ & $\begin{array}{l}110 \\
107\end{array}$ & $\begin{array}{l}110 \\
107\end{array}$ & $\begin{array}{l}0.102 \\
0.085\end{array}$ & 0.065 \\
\hline $\begin{array}{l}163583 \\
128683\end{array}$ & $Y-12$ & 100 & 12 & 68 & 63 & -0.316 & -0.374 & 68 & 68 & -0.318 & -0.318 \\
\hline 115558 & $Y-12$ & 100 & $9 \mathbf{a}$ & 113 & 101 & 0.130 & 0.005 & 113 & 113 & 0.127 & 0.127 \\
\hline 125126 & $Y-12$ & 100 & $9 \mathbf{a}$ & 110 & 102 & 0.104 & 0.024 & 110 & 110 & 0.101 & 0.101 \\
\hline 145525 & $x-10$ & 500 & $9 a$ & 590 & 539 & 0.179 & 0.078 & 588 & 888 & 0.175 & 0.176 \\
\hline 177295 & $x-10$ & 500 & $9 a$ & 612 & 587 & 0.223 & 0.174 & 610 & 610 & 0.219 & 0.219 \\
\hline 169224 & $x-10$ & 500 & 9a & 595 & 584 & 0.191 & 0.169 & 593 & 503 & 0.187 & 0.187 \\
\hline 121704 & $Y-12$ & 500 & 12 & 374 & 358 & -0.253 & -0.284 & 372 & 372 & -0.255 & -0.256 \\
\hline 178817 & $Y-12$ & 500 & $8 a$ & 618 & 595 & 0.235 & 0.191 & 616 & 616 & 0.231 & 0.231 \\
\hline 120753 & $Y-12$ & 500 & $8 a$ & 629 & 611 & 0.259 & 0.222 & 627 & 627 & 0.255 & 0.256 \\
\hline
\end{tabular}

Final Reported Dose

Supralinaarity (SL) Correctea

$\begin{array}{cccc}\begin{array}{c}\text { Rep. } \\ \text { Hd }\end{array} & \begin{array}{c}\text { Rep. } \\ \text { Hs }\end{array} & \begin{array}{c}\text { PQ } \\ \text { Hd }\end{array} & \begin{array}{c}\text { HQ } \\ \text { Hs }\end{array} \\ 100 & 100 & -0.002 & -0.002 \\ 105 & 105 & 0.049 & 0.049 \\ 101 & 101 & 0.014 & 0.014 \\ 68 & 68 & -0.318 & -0.318 \\ 107 & 107 & 0.073 & 0.073 \\ 105 & 105 & 0.048 & 0.048 \\ 433 & 520 & -0.133 & 0.040 \\ 448 & 539 & -0.104 & 0.078 \\ 437 & 525 & -0.126 & 0.050 \\ 284 & 284 & -0.432 & -0.432 \\ 452 & 544 & -0.096 & 0.088 \\ 460 & 554 & -0.080 & 0.109 \\ & & -0.202 & \end{array}$


Cs-137 Exposures Processed with $10 \%$ Traneniseion Iiter.

Step cases $8 c, 10 c, 11 c$ chosen.

\begin{tabular}{|c|c|c|c|c|c|c|c|c|c|c|c|}
\hline \multirow[b]{2}{*}{$\begin{array}{l}\text { HBG } \\
\text { No. }\end{array}$} & \multirow[b]{2}{*}{ PC } & \multirow[b]{2}{*}{$\begin{array}{l}\text { Del. H } \\
\text { (RAD) }\end{array}$} & \multirow[b]{2}{*}{$\begin{array}{l}\text { Step } \\
\text { Case }\end{array}$} & \multicolumn{4}{|c|}{ Uncorrected Dose (H) } & \multicolumn{4}{|c|}{ Fade Corrected Dose } \\
\hline & & & & $\begin{array}{l}\text { Rep. } \\
\text { Hd }\end{array}$ & $\begin{array}{c}\text { Rep. } \\
\text { Hs }\end{array}$ & $\begin{array}{l}P Q \\
H d\end{array}$ & $\begin{array}{l}P Q \\
H S\end{array}$ & $\begin{array}{l}\text { Rep. } \\
\text { Hd }\end{array}$ & $\begin{array}{c}\text { Rep. } \\
\text { Hs }\end{array}$ & $\begin{array}{l}P Q \\
\mathrm{Hd}\end{array}$ & $\begin{array}{l}\text { PQ } \\
\text { Hs }\end{array}$ \\
\hline 110629 & $x-10$ & 0.500 & 12 & 0.328 & 0.325 & -0.349 & -0.350 & 0.325 & 0.326 & -0.351 & -0.351 \\
\hline 102178 & $x-10$ & 0.500 & 12 & 0.327 & 0.322 & -0.347 & -0.357 & 0.325 & 0.325 & -0.349 & -0.349 \\
\hline 121861 & $x-10$ & 0.500 & gc & 0.506 & 0.508 & 0.012 & 0.016 & 0.504 & 0.507 & 0.009 & 0.013 \\
\hline 152337 & $Y-12$ & 0.500 & $11 c$ & 0.388 & 0.516 & -0.225 & 0.033 & 0.386 & 0.515 & -0.227 & 0.029 \\
\hline 121203 & $Y-12$ & 0.500 & $9 c$ & 0.487 & 0.466 & -0.026 & -0.067 & 0.486 & 0.486 & -0.029 & -0.029 \\
\hline 138927 & $Y-12$ & 0.500 & gc & 0.519 & 0.508 & 0.039 & 0.015 & 0.518 & 0.518 & 0.036 & 0.036 \\
\hline 162421 & $x-10$ & 1.000 & gc & 1.009 & 0.932 & 0.009 & -0.088 & 1.008 & 1.008 & 0.006 & 0.006 \\
\hline 110668 & $x-10$ & 1.000 & 9c & 0.978 & 0.862 & -0.024 & -0.038 & 0.973 & 0.973 & -0.027 & -0.027 \\
\hline 102972 & $x-10$ & 1.000 & gc & 0.894 & 0.984 & -0.006 & -0.006 & 0.991 & 0.991 & -0.009 & -0.009 \\
\hline 125480 & $Y-12$ & 1.000 & 12 & 0.637 & 0.623 & -0.363 & -0.377 & 0.635 & 0.636 & -0.365 & -0.365 \\
\hline 151146 & $Y-12$ & 1.000 & $10 c$ & 0.805 & 1.554 & -0.095 & 0.554 & 0.902 & 1.549 & -0.098 & 0.549 \\
\hline 113507 & $Y-12$ & 1.000 & $9 c$ & 0.837 & 0.930 & -0.063 & -0.070 & 0.934 & 0.834 & -0.066 & -0.066 \\
\hline 163925 & $x-10$ & 10 & gc & 9.50 & 8.60 & -0.050 & -0.140 & 8.47 & 9.47 & -0.053 & -0.053 \\
\hline 160623 & $x-10$ & 10 & $8 c$ & 9.39 & 9.15 & -0.081 & -0.085 & 9.36 & 9.36 & -0.084 & -0.054 \\
\hline 139160 & $x-10$ & 10 & 9c & 9.40 & 9.02 & -0.080 & -0.098 & 9.37 & 9.37 & -0.063 & -0.063 \\
\hline 106014 & $Y-12$ & 10 & gc & 9.69 & 8.94 & -0.031 & -0.106 & 9.65 & 9.65 & -0.035 & -0.035 \\
\hline 175296 & $Y-12$ & 10 & oc & 9.60 & 8.98 & -0.040 & -0.101 & 9.57 & 9.67 & -0.043 & -0.043 \\
\hline 127728 & $Y-12$ & 10 & gc & 9.60 & 9.54 & -0.040 & -0.046 & 9.57 & 9.67 & -0.043 & -0.043 \\
\hline 122584 & $x-10$ & 50 & gc & 47.94 & 41.34 & -0.041 & -0.173 & 47.79 & 47.79 & -0.044 & -0.044 \\
\hline 140479 & $x-10$ & 50 & gc & 47.15 & 43.23 & -0.057 & -0.135 & 46.89 & 46.99 & -0.060 & -0.060 \\
\hline 123418 & $x-10$ & 50 & sc & 47.65 & 44.96 & -0.047 & -0.101 & 47.49 & 47.49 & -0.050 & -0.050 \\
\hline 111246 & $Y-12$ & 50 & gc & 49.80 & 44.04 & -0.002 & -0.119 & 49.74 & 49.74 & -0.005 & -0.005 \\
\hline 180874 & $Y-12$ & 50 & $\theta$ & 52.97 & 46.60 & 0.059 & -0.068 & 52.80 & 52.80 & 0.056 & 0.056 \\
\hline & & 50 & $9 c$ & 47.69 & 48.12 & -0.046 & -0.038 & 47.54 & 47.96 & -0.049 & -0.041 \\
\hline
\end{tabular}

Final Reported Dose

Supralinearity (SL) Corrected

$\begin{array}{cccc}\begin{array}{c}\text { Rep. } \\ \text { Hd }\end{array} & \begin{array}{c}\text { Rep. } \\ \text { Hs }\end{array} & \text { HQ } & \text { PQ } \\ & & & \text { Hs } \\ 0.325 & 0.325 & -0.351 & -0.351 \\ 0.325 & 0.325 & -0.349 & -0.349 \\ 0.504 & 0.507 & 0.009 & 0.013 \\ 0.386 & 0.515 & -0.227 & 0.029 \\ 0.486 & 0.486 & -0.029 & -0.029 \\ 0.518 & 0.518 & 0.036 & 0.036 \\ 1.006 & 1.006 & 0.006 & 0.006 \\ 0.973 & 0.973 & -0.027 & -0.027 \\ 0.991 & 0.991 & -0.009 & -0.009 \\ 0.635 & 0.636 & -0.365 & -0.365 \\ 0.902 & 1.549 & -0.098 & 0.549 \\ 0.934 & 0.934 & -0.066 & -0.066 \\ 9.467 & 9.467 & -0.053 & -0.053 \\ 9.362 & 9.362 & -0.064 & -0.064 \\ 9.372 & 9.372 & -0.063 & -0.063 \\ 9.655 & 9.656 & -0.035 & -0.035 \\ 9.570 & 9.570 & -0.043 & -0.043 \\ 9.567 & 9.667 & -0.043 & -0.043 \\ 47.79 & 47.79 & -0.044 & -0.044 \\ 46.99 & 46.99 & -0.060 & -0.060 \\ 47.49 & 47.49 & -0.050 & -0.050 \\ 49.74 & 49.74 & -0.005 & -0.005 \\ 52.80 & \mathbf{5 2 . 8 0} & 0.056 & 0.056 \\ 47.54 & 47.96 & -0.049 & -0.041\end{array}$


Step cases $8 c, 10 c, 11 c$ chosen, Continued.

\begin{tabular}{|c|c|c|c|c|c|c|c|}
\hline \multirow[b]{2}{*}{$\begin{array}{l}\text { HBG } \\
\text { No. }\end{array}$} & \multirow[b]{2}{*}{ PC } & \multirow[b]{2}{*}{$\begin{array}{l}\text { Del. H } \\
\text { (RAD) }\end{array}$} & \multirow[b]{2}{*}{$\begin{array}{l}\text { Step } \\
\text { Case }\end{array}$} & \multicolumn{3}{|c|}{ Uncorrected Dose (H) } & \multirow[b]{2}{*}{$\begin{array}{l}\mathrm{PQ} \\
\mathrm{HS}\end{array}$} \\
\hline & & & & $\begin{array}{c}\text { Rep. } \\
\text { Hd }\end{array}$ & $\begin{array}{c}\text { Rep. } \\
\text { Hs }\end{array}$ & $\begin{array}{l}\mathrm{PQ} \\
\mathrm{Hd}\end{array}$ & \\
\hline 139468 & $x-10$ & 100 & 9c & 95 & 86 & -0.050 & -0.142 \\
\hline 164234 & $x-10$ & 100 & 9c & 100 & 85 & -0.002 & -0.148 \\
\hline 163583 & $x-10$ & 100 & 9c & 97 & 89 & -0.035 & -0.115 \\
\hline 126883 & $Y-12$ & 100 & 12 & 68 & 63 & -0.316 & -0.374 \\
\hline 115558 & $Y-12$ & 100 & $9 c$ & 102 & 89 & 0.021 & -0.106 \\
\hline 125126 & $Y-12$ & 100 & $9 c$ & 100 & 91 & -0.003 & -0.089 \\
\hline 145525 & $x-10$ & 500 & $9 c$ & 533 & 479 & 0.065 & -0.041 \\
\hline 177295 & $x-10$ & 500 & $9 c$ & 552 & 522 & 0.105 & 0.043 \\
\hline 169224 & $x-10$ & 500 & 8c & 538 & 519 & 0.075 & 0.039 \\
\hline 121704 & $Y-12$ & 500 & 12 & 374 & 358 & -0.253 & -0.284 \\
\hline 178817 & Y-12 & 500 & $9 c$ & 558 & 529 & 0.116 & 0.059 \\
\hline 120753 & $Y-12$ & 500 & $9 c$ & 568 & 543 & 0.137 & 0.086 \\
\hline
\end{tabular}

\section{Fade Corrected Dose}

$\begin{array}{cccc}\text { Rep. } & \text { Rep. } & \text { PQ } & \text { PQ } \\ \text { Hd } & \text { Hs } & \text { Hd } & \text { Hs }\end{array}$

$\begin{array}{llll}95 & 95 & -0.053 & -0.053\end{array}$

$\begin{array}{llll}99 & 99 & -0.005 & -0.005\end{array}$

$\begin{array}{llll}96 & 96 & -0.038 & -0.038\end{array}$

$\begin{array}{llll}68 & 68 & -0.318 & -0.318\end{array}$

$\begin{array}{llll}102 & 102 & 0.017 & 0.017\end{array}$

$\begin{array}{llll}99 & 99 & -0.006 & -0.006\end{array}$

$\begin{array}{llll}531 & 531 & 0.062 & 0.062\end{array}$

$\begin{array}{llll}551 & 551 & 0.101 & 0.101\end{array}$

$\begin{array}{llll}536 & 536 & 0.072 & 0.072\end{array}$

$\begin{array}{llll}372 & 372 & -0.255 & -0.265\end{array}$

$\begin{array}{llll}556 & 566 & 0.112 & 0.112\end{array}$

$\begin{array}{llll}567 & 567 & 0.133 & 0.133\end{array}$
Final Reported Dose

Supralinearity (SL) Corrected

Rep. Rep. PQ PQ

Hd Hs Hd Hs

$\begin{array}{cccc}95 & 96 & -0.053 & -0.053 \\ 99 & 99 & -0.005 & -0.005 \\ 96 & 96 & -0.038 & -0.038 \\ 68 & 68 & -0.318 & -0.318 \\ 97 & 97 & -0.031 & -0.031 \\ 99 & 99 & -0.006 & -0.006 \\ 395 & 471 & -0.211 & -0.059 \\ 408 & 488 & -0.184 & -0.025 \\ 398 & 476 & -0.204 & -0.050 \\ 284 & 284 & -0.432 & -0.432 \\ 412 & 492 & -0.176 & -0.015 \\ 419 & \mathbf{5 0 2} & -0.162 & 0.003\end{array}$


Appendix B

GRAPH CHARTS 
18 Tranomiseion Filter. 8top caee 9a, $10 \mathrm{~b}$.

Ce-137 Exposures-Deop Dose

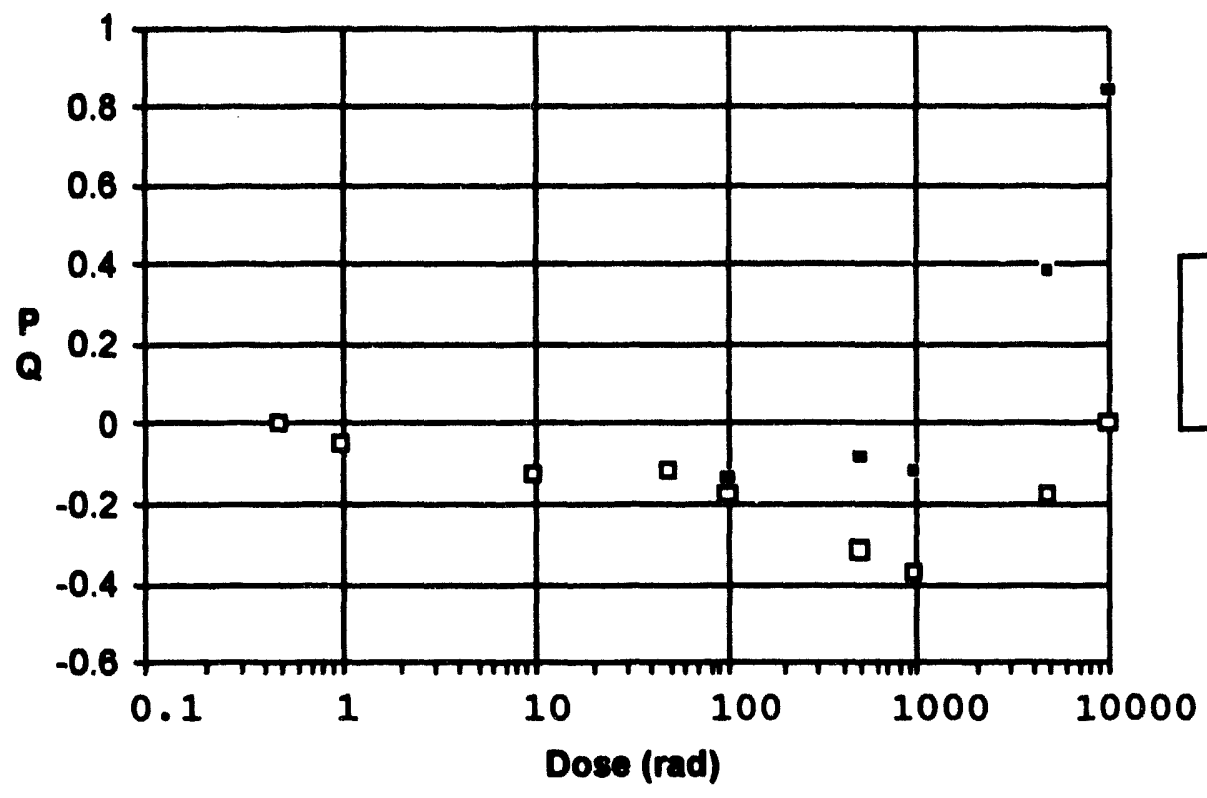

18 Tranamision Filtor. 8top cases 90, 100. C8-137 Exposure-Deop Dose

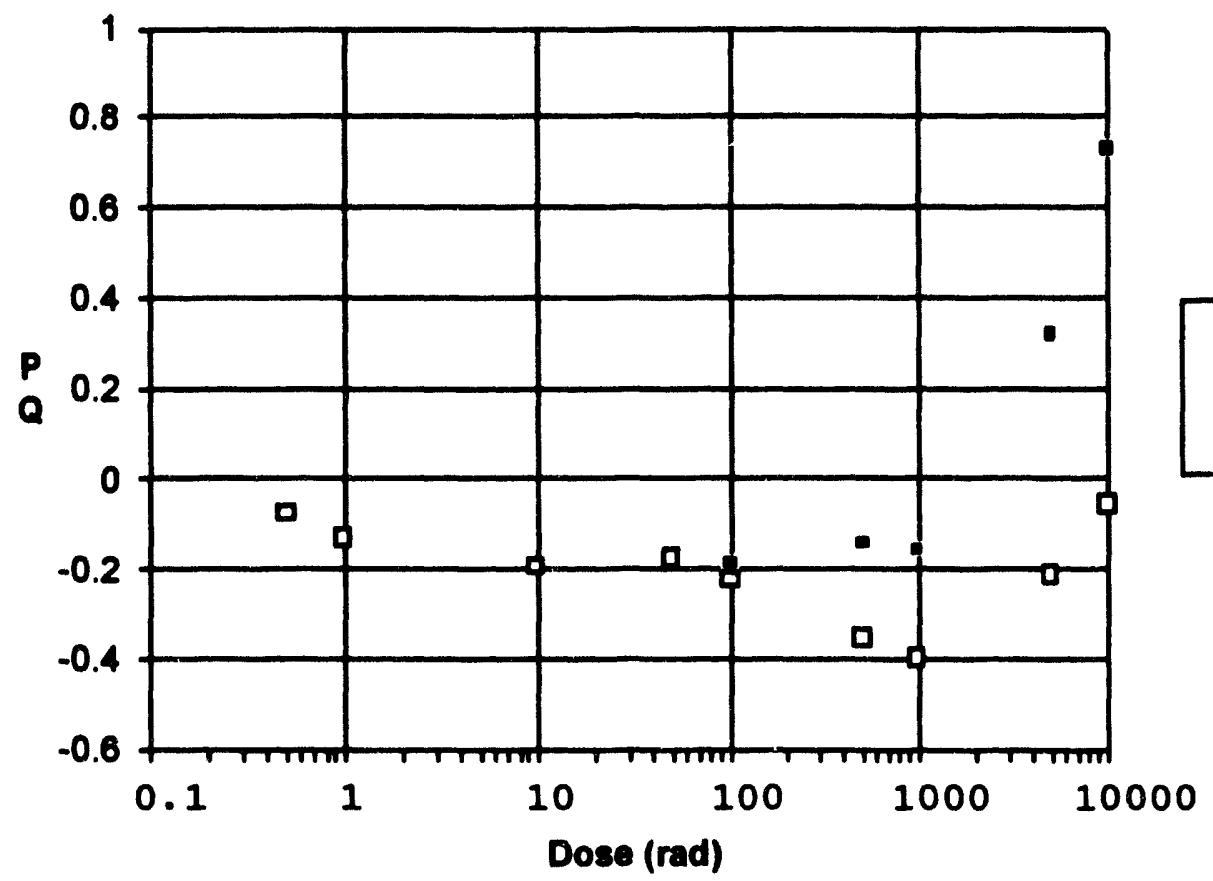

- Fade Corrected

- Fade and SL Corrected
- Fade Corrected

- Fade and SL Corrected 
18 Tranonieaion F11ter. 8top Cace 9a, $10 \mathrm{~b}$.

C8-137 Exposures-8hallow Dose

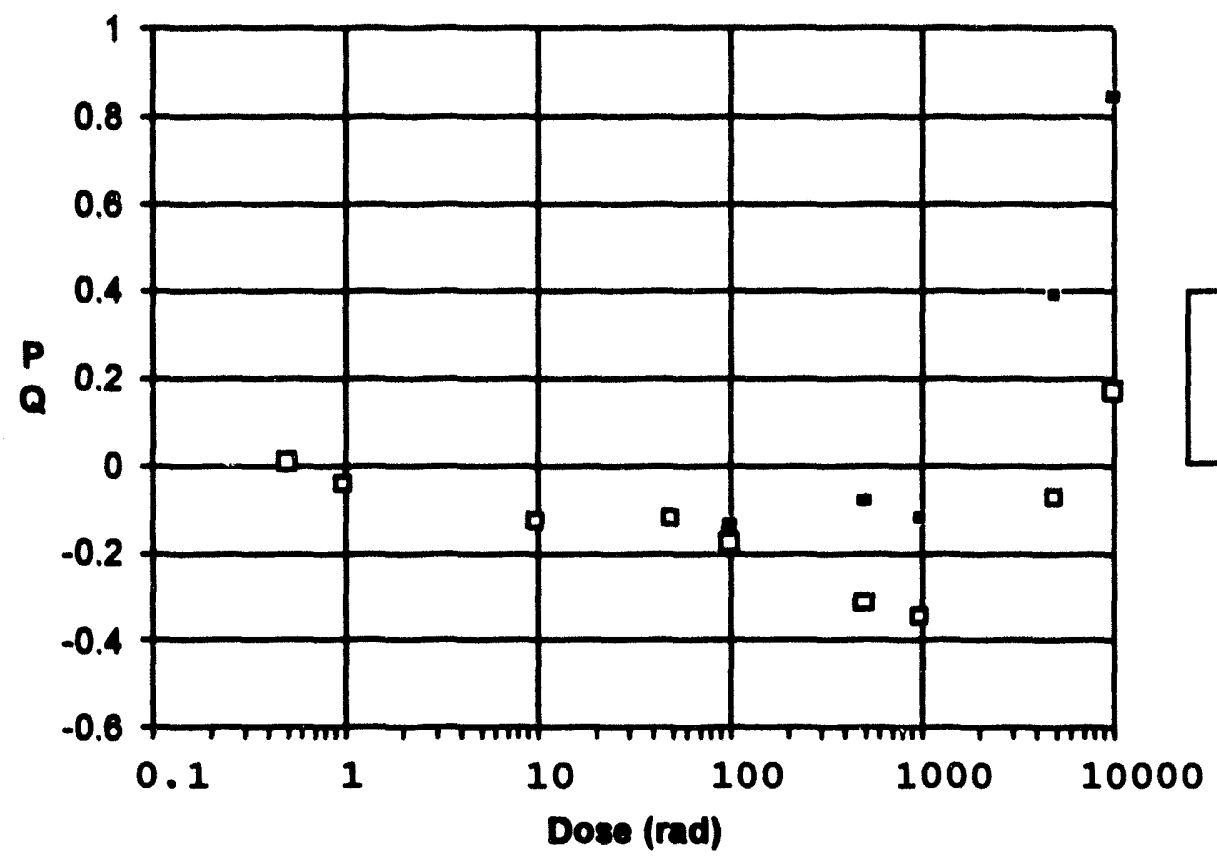

18 Tranoniseion. Filtor. 8top Cases 12, 90, 100. Ce-137 Exposures-8hal10w Dose

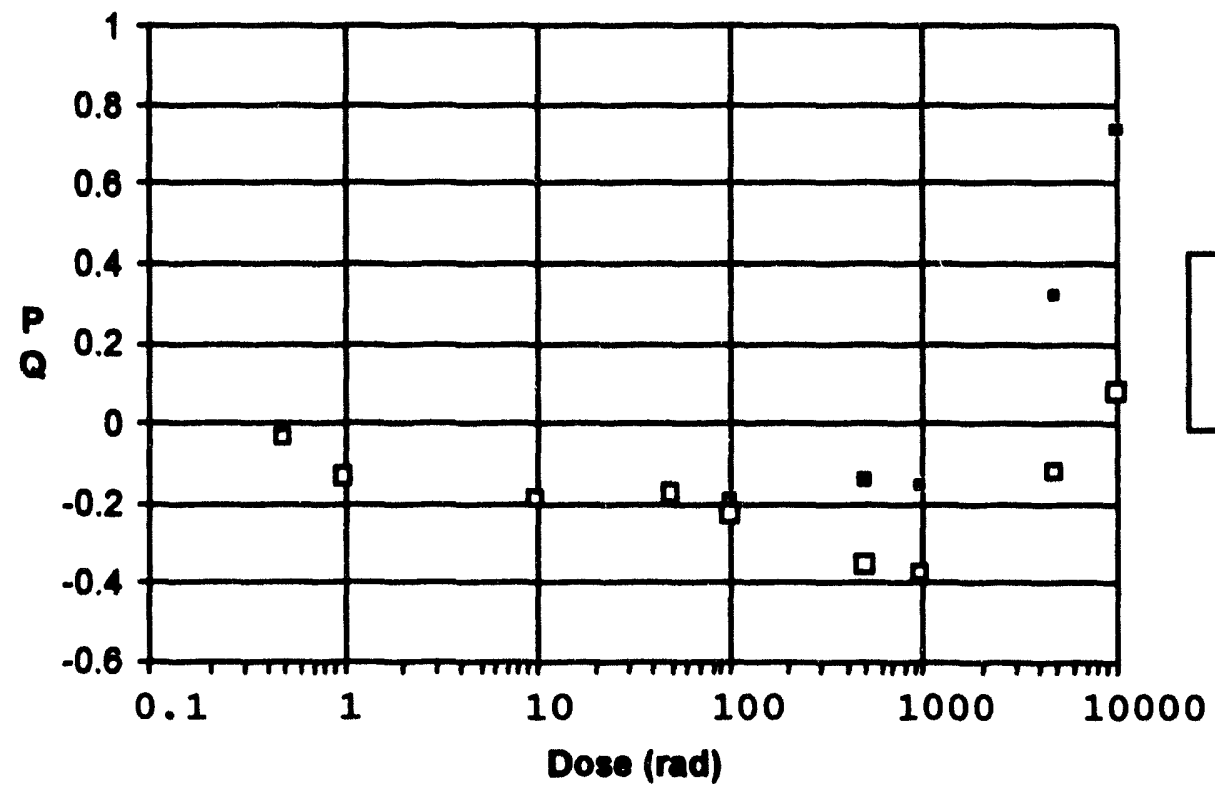

- Fade Corrected

- Fade and SL Corrected

- Fade Corrected

- Fade and SL Corrected 
Nuclear Accident Dosimeter Processing with Attenuation Filters

$10 \%$ Trananiasion Filter. stop cases 9a, 10b, $11 \mathrm{~b}$.

Ca-137 Exposures-Deep Dose

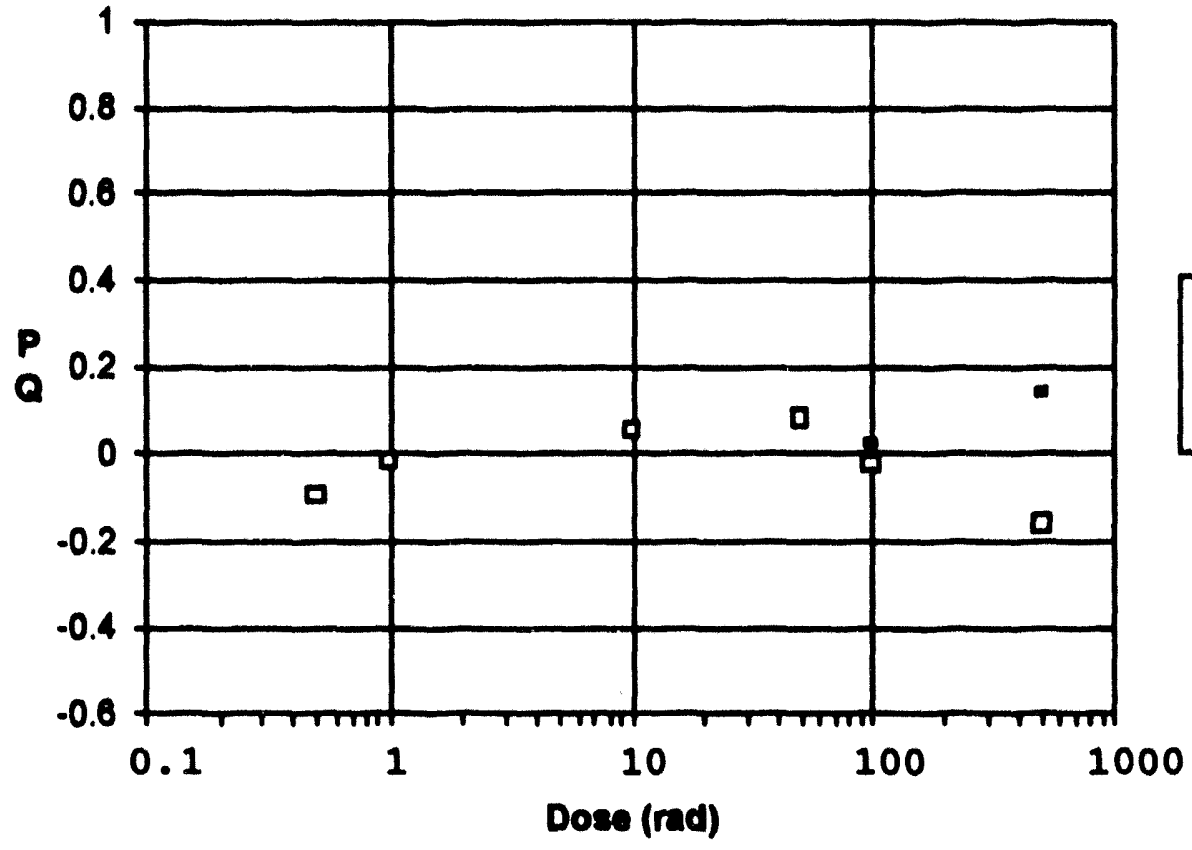

108 Tranoniseion Jilter, stop cases $90,100,110$.

Ca-237 Exposures-DeOp DOse

- Fade Corrected

- Fade and SL Corrected

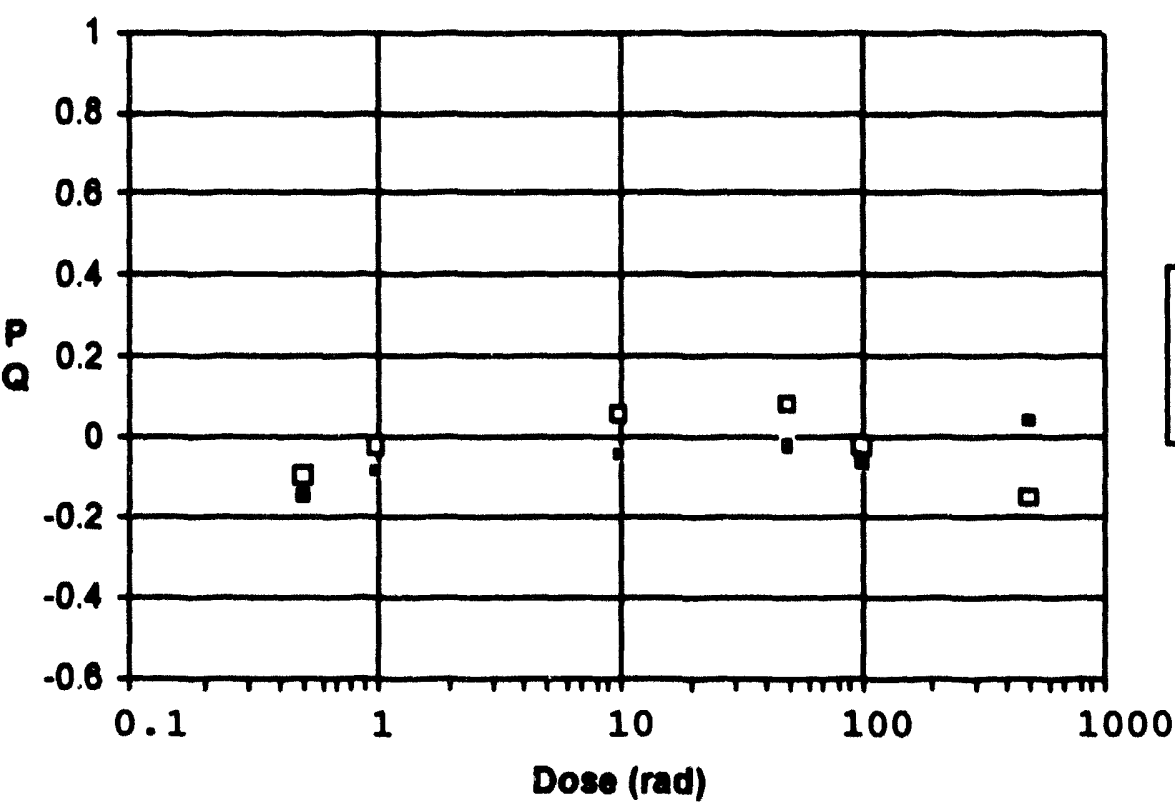

- Fade Corrected

- Fade and SL Corrected 
$10 \%$ Trananiedon F11tex, step cases $90,100,110$. ce-137 Ixpoeures-8hal10w Doee

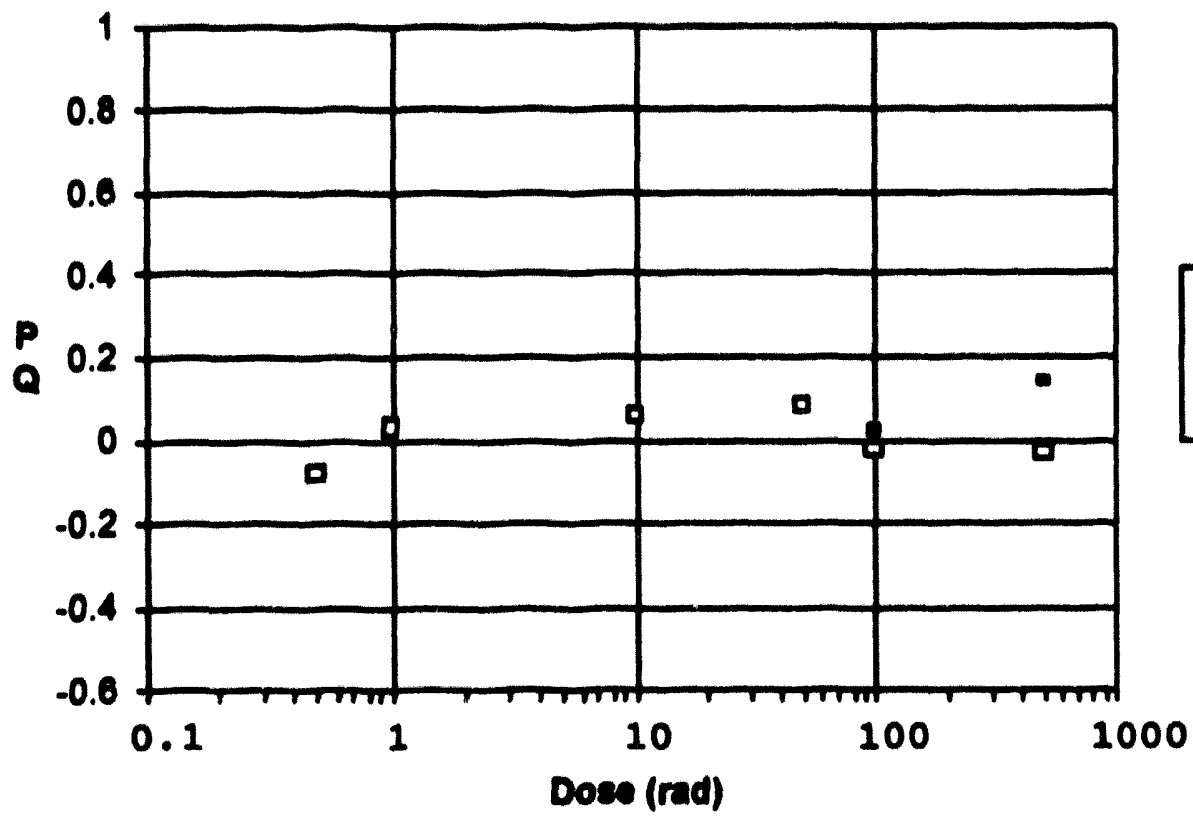

- Fade Corrected

- Fade and SL Corrected

10t Tranoniesion I11ter, stop Cases 90, 100, 110.

co-137 Epooures-8he110w Dose

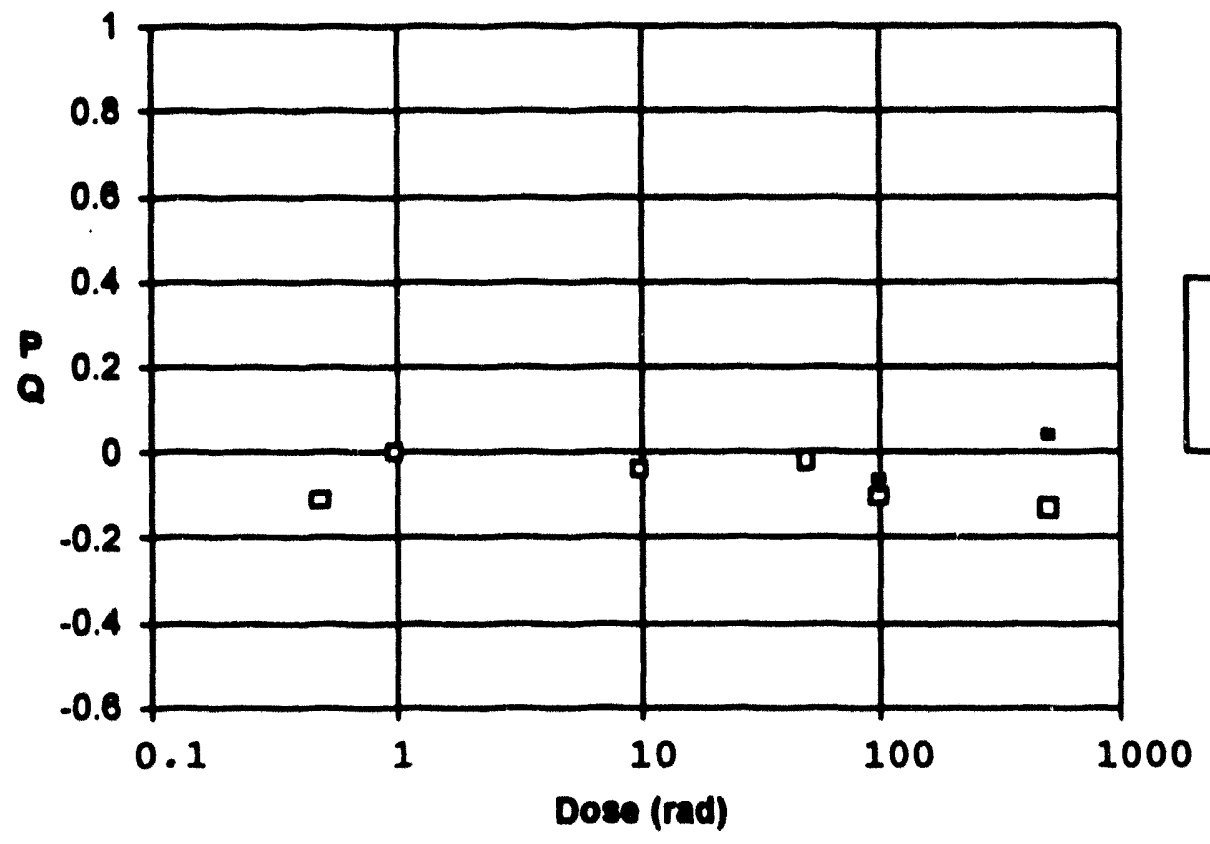

- Fade Corrected

- Fade and SL Corrected 


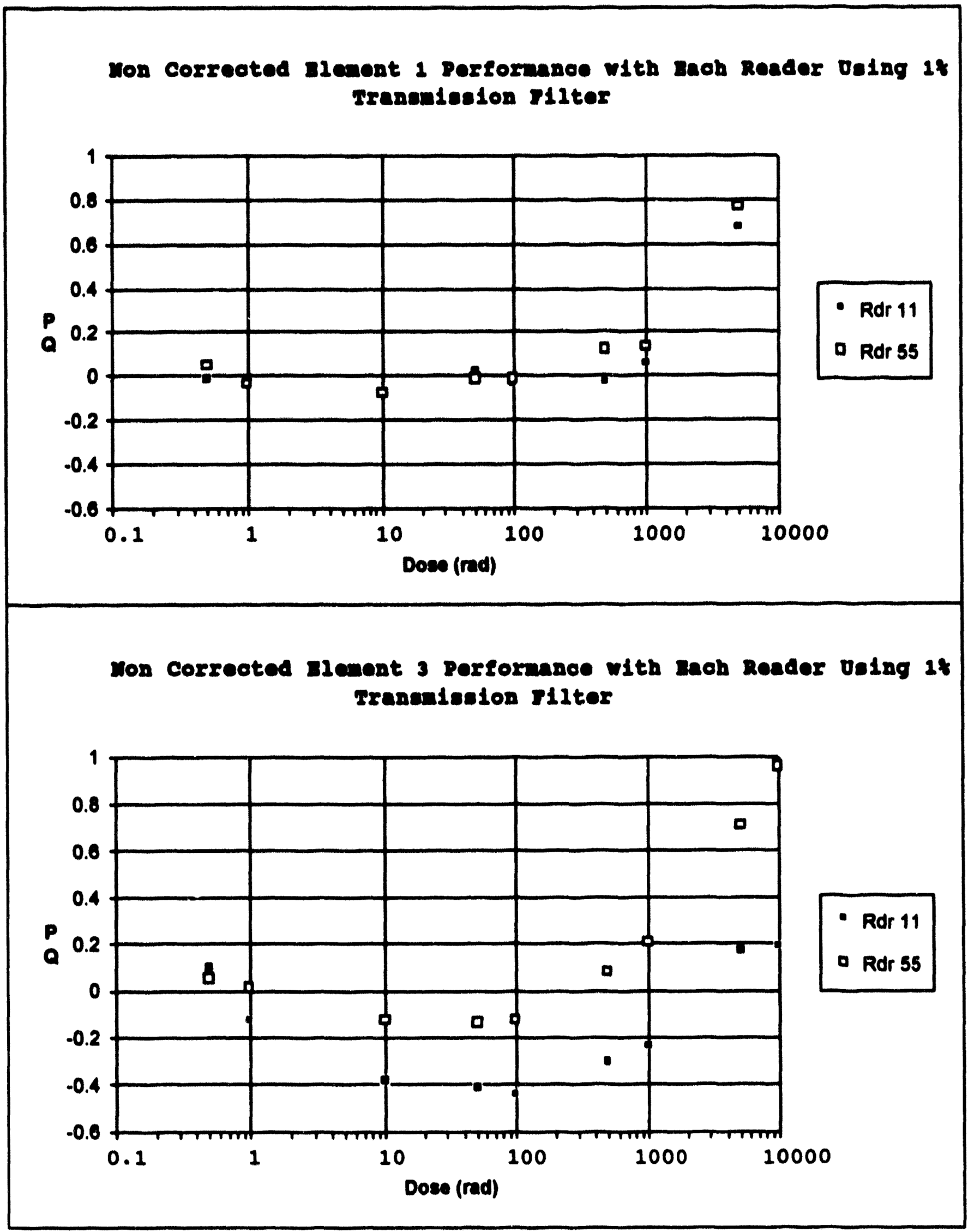


INTERNAL DISTRIBUTION

1. A. B. Ahmed

2. A. D. Arnwine

3. D. S. Colwell

4. S. W. Croslin

5. R. W. Fiolds, Jr.

6-10. R. J. Gunter

11. K. L. McMahan

12. G. T. Mol

13. K. R. Shaw
14. D. E. Somers

15. E. Sonder

16. N. A. Teasloy III

17-18. Central Research Library

19-20. Laboratory Records

21. Laboratory Records-RC

22. ORNL Y-12 Technical Lubrary

23. Document Reference Section

24. ORNL Patent Section

\section{EXTERNAL DISTRIBUTION}

25. Office of Assistant Manager for Energy Research and Development, Department of Energy, Oak Ridge Operations, P.O. Box 2001, Oak Ridge, TN 37831-8600

26-27. Office of Scientific and Technical Information, P.O. Box 62, Oak Ridge, TN 37831

28. H. J. Monroe, Department of Energy, Oak Ridge Operations, P.O. Box 2001, Oak Ridge, TN 37831

29. R. A. Tawil, Harshaw/Bicron Radiation Measurement Products, 6801 Cochran Road, Solon, $\mathrm{OH} 44139$ 

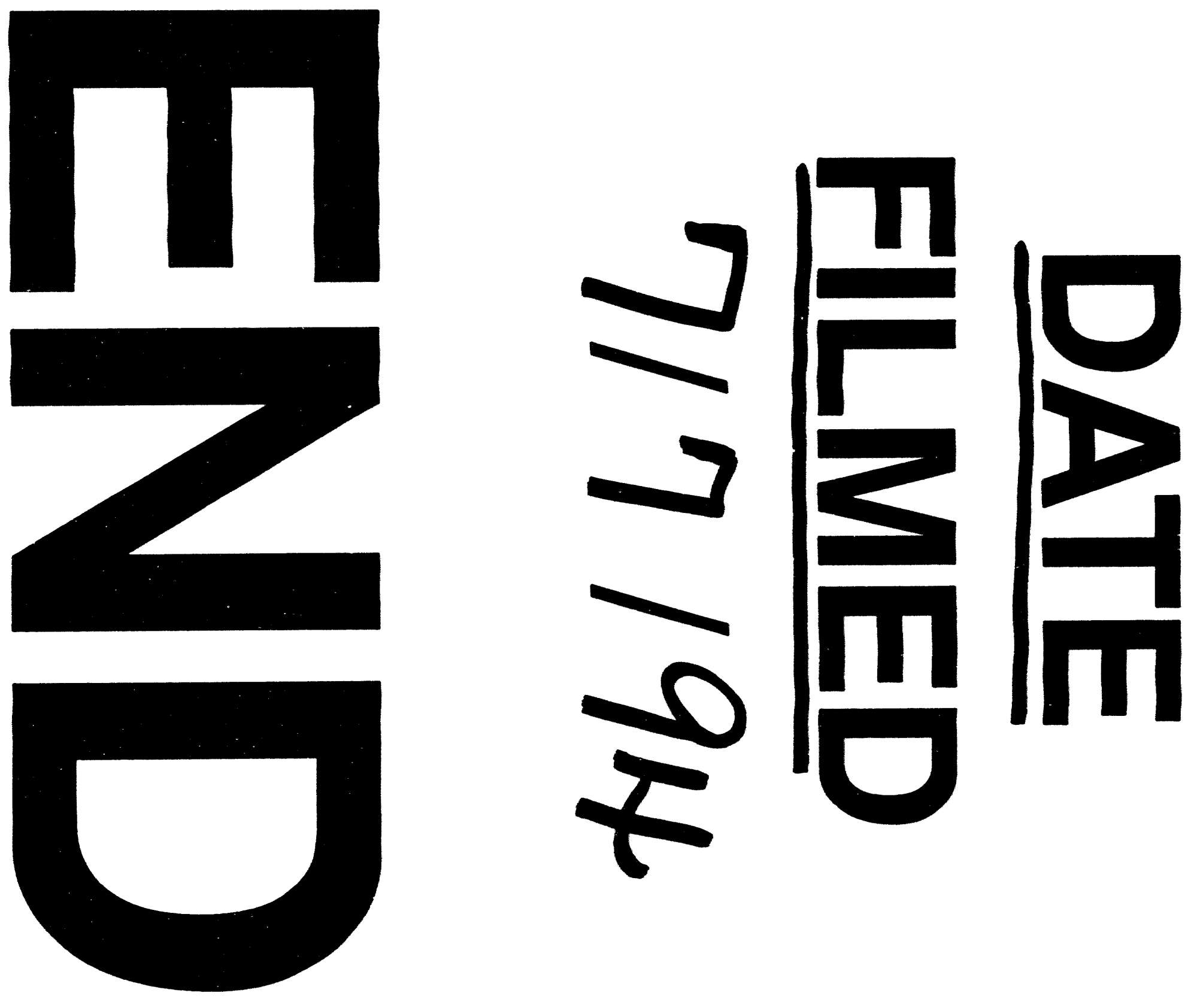


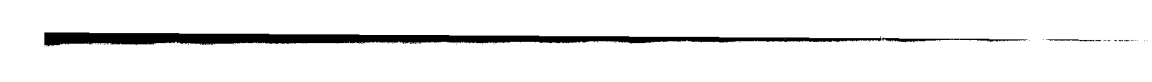

…

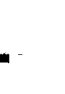

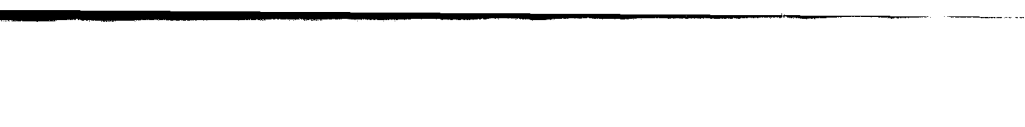

